\author{
В.А. Ковтун, Д.П. Колесников, М.В. Супотницкий, Н.И. Шило \\ Федеральное государственное бюджетное учреждение \\ "27 Научный иентр» Министерства обороны Российской Федерации, \\ 105005, Российская Федерация, г. Москва, Бригадирский переулок, д. 13
}

Поступила 27.07.2018 г. Принята к публикации 10.09.2018 г.

Приведенные в статье данные показывают, что Сирийская Арабская Республика (САР) была обречена на уничтожение коллективным Западом по крайней мере с 2002 г. в рамках процесса по фрагментации государств Большого Ближнего Востока и приведению к власти в этих странах «Братьев-мусульман». Позже этот процесс был назван «Арабской весной». Анализ якобы «фактов» применения химического оружия вооруженными силами САР позволил установить, что все они - не более, чем примитивно выполненные постановки. Ни одно «химическое нападение» в Сирии, приписываемое сирийской армии, не преследовало военных целей, принципы боевого применения химического оружия не соблюдались, не зафиксировано ни одного случая использования химических боеприпасов заводского производства. Информационные вбросы западных СМИ и неправительственных организаций о ведущейся сирийским правительством «химической войне против своего народа» осуществлялись для поддержки антиправительственных сил в Сирии в моменты их наступления на подконтрольные правительству территории, либо когда они терпели поражение от сирийской армии. Для более убедительных «картинок» оппозиционерами с 2013 г. практиковались (и практикуются в настоящее время) массовые похищения и убийства детей. Но даже при освещении в западной прессе этих преступлений, они не интересовали ни правительства западных стран, ни западные правозащитные организации. Представлены данные, свидетельствующие о системных сбоях и недостатках в работе Совместного механизма расследования фактов применения химического оружия ОЗХО - ООН, а также миссий ОЗХО по установлению фактов его применения. Рассматривая химические фейки в Сирии в контексте современной геополитики, можно предположить, что речь идет о формировании очередного «крестового похода» на Россию и ее союзников, но уже с применением оружия массового поражения. При ретроспективном анализе механизмов ведения информационной войны и качества ее постановочной части, наблюдается их глубокая интеллектуальная деградация по сравнению с аналогичными информационными операциями 1990-х гг., что создает серьезную опасность уже не только Сирии и России, но и другим странам, так как их организаторы явно не способны оценивать даже ближайшие последствия своих действий.

Ключевые слова: авиационный химический боеприпас; «Белье каски»; «Братья-мусульмане»; бинарный химический боеприпас; дегазачия; зарин; ОЗХО; отравляющее вещество; Сирийская Арабская Республика; токсичный химикат; химическая война; хлор.

Библиографическое описание: Ковтун В.А., Колесников Д.П., Супотницкий М.В., Шило Н.И. Сирийская «химическая война» // Вестник войск РХБ защитыь. 2018. Т. 2. № 3. С. 7-39.

С августа 2013 г. тема химической войны в Сирии неоднократно становилась предлогом для применения военной силы НАТО против
Сирийской Арабской Республики (САР). Нет оснований сомневаться в том, что «химическая война» в Сирии действительно ведется, но это не 


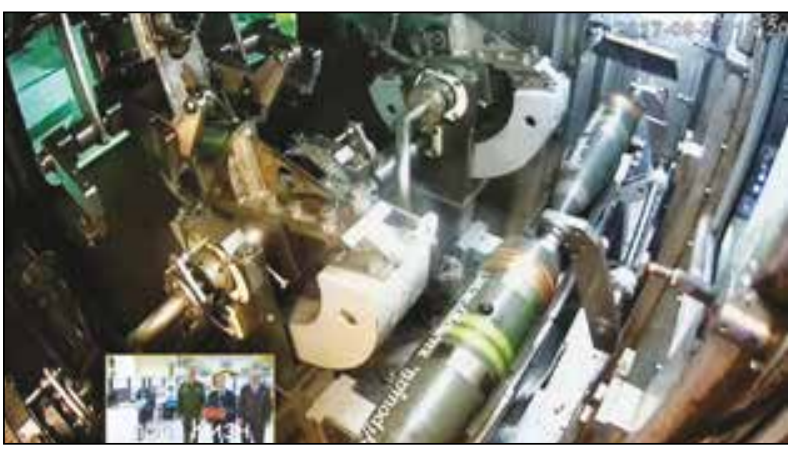

Рисунок 1 - Уничтожение последнего российского химического снаряда на заводе по уничтожению химического оружия «Кизнер» (Удмуртия), 27 сентября 20172.

та война, правила которой определены в старых боевых уставах и наставлениях. Ее жертвы не отдельные люди, попавшие под разрыв химического боеприпаса, а миллионы тех, кого убили, покалечили, превратили в беженцев борцы с «тираном, применяющим химическое оружие против своего народа». Уникальна эта война и по ее исполнению. Отравляющие вещества (OB) используются минимально, основное «средство массового поражения» беспринципная ложь западных политиков о борьбе за демократию; основная пехота - интернациональные группировки убийц-джихадистов; информационное прикрытие совершаемых преступлений - респектабельные глобальные масс-медиа. Своим острием эта война обращена в будущее, причем прежде всего - в наше будущее, так как она несет в себе законный casus belli - повод к коалиционной войне Запада и ряда стран Ближнего Востока не только против Сирии, но и России, как стран, якобы нарушивших Конвенцию о запрещении химического оружия (КХO) ${ }^{1}$.

Цель настоящей работы - рассмотреть химическую войну в Сирии в ее реальности. Нами решались следующие задачи: на основе опыта Первой мировой войны показать, что собой представляет в действительности химическое оружие и как оно применялось и будет применяться в реальной войне; рассмотреть события, приведшие к войне в Сирии; хронологизировать события химической войны в Сирии; выявить основные приемы и средства ее ведения; оценить эффективность Миссий по установлению фактов применения химического оружия (МУФ), созданных Организацией по запрещению химического оружия (O3XO) и Совместного механизма по рассле- дованию фактов применения химического оружия (СМР). Мы не ставили своей задачей что-то доказать тем, кто последовательно и бескомпромиссно использует тему химической войны в Сирии в своих глобальных целях. Но кроме них есть и те, кто хочет знать правду, им предназначается эта статья.

Химическое оружие и его боевое применение. Химическое оружие и химическая война - это западные изобретения. Все работы по химическому оружию в Российской Империи и в СССР носили ответный характер. В настоящее время Россия не обладает химическим оружием (рисунок 1).

Впервые план химического нападения на позиции упорного противника был подготовлен в 1855 г. британским лордом Томасом Дандональдом (Thomas Dundonald, 1778-1860) в связи с критичным положением войск Французской, Британской, Османской империй и их союзников под Севастополем. Он представил британскому правительству секретный меморандум, где предложил атаковать русских, засевших на Малаховом кургане, облаком сернистого ангидрида (сернистый газ, $\mathrm{SO}_{2}$ ). Дандональд привел расчет, сделанный знаменитым британским химиком Майклом Фарадеем (Michael Faraday, 1791-1867), показывавший, что для удушения защитников Малахова кургана сернистым газом надо поджечь смесь из 500 т серы и 2 тыс. т каменного угля. Такая смесь при сгорании дала бы не менее тысячи тонн сернистого ангидрида. План не был приведен в действие, но сохранялся в секрете до начала Первой мировой войны [1].

Но в конце 1914 г. старый план послужил толчком для британской программы по созданию химического оружия, когда до германской газобаллонной атаки под Ипром 22 апреля 1915 г. еще оставалось полгода [2]. В марте 1915 г., т.е. за месяц до германского газопуска под Ипром, на британских полигонах проходили сравнительные испытания нескольких образцов химических снарядов [3].

Параллельно работы по химическому оружию вели германские и французские химики. Французские военные уже в сентябре 1914 г. применяли 26-мм ружейную гранату с этилбромацетатом образца 1912 г. В марте 1915 г. (т.е. за месяц до германской газобаллонной атаки под Ипром) французы сформировали химические минометные части [3].

Химическая война, вне зависимости от того, организовали бы немцы 22 апреля 1915 г. газобаллонную атаку под Ипром или нет, все

\footnotetext{
${ }^{1}$ Конвенция о запрещении разработки, производства, накопления и применения химического оружия и его уничтожении (КХО) - соглашение по контролю за вооружениями, которое запрещает производство, накопление и применение химического оружия. Главным обязательством конвенции, налагаемым на ее участников, является запрет на производство и применение химического оружия, а также уничтожение всех его запасов.
} 
равно бы началась. В условиях позиционного тупика на Западном фронте, сложившегося к концу 1914 г., когда все имевшиеся средства прорыва обороны противника у воюющих сторон исчерпали свои возможности, она была единственным выходом.

К концу Первой мировой войны химическое оружие стало оружием поля боя. Воюющие стороны использовали его во всех операциях завершающего периода войны миллионами боеприпасов и десятками тысяч тонн $\mathrm{OB}^{2}$. В боевых условиях проверена поражающая эффективность 45 OB. Химические боеприпасы были представлены артиллерийскими снарядами различного тактического назначения и калибра, газометными и минометными минами, ручными химическими гранатами. Проводились эксперименты по применению химических авиационных бомб и авиационных выливных приборов (ВАП). Газопуски утратили боевое значение в 1916 г. К концу войны из-за малой токсичности хлор считался не самостоятельным ОВ, имеющим собственное боевое значение, а лишь прекурсором для синтеза других ОВ (фосген, хлорпикрин, дифенилхлорарсин, хлорное олово и др.) $[4,5]$.

Первая мировая война закончилась на рубеже перехода от использования химического оружия для решения тактических задач (артиллерия) к решению задач оперативного масштаба (авиация). Воюющими сторонами эмпирически, ценой десятков тысяч жертв, удалось разработать основные принципы применения химического оружия:

принцип максимальной кониентрации $O B$ - для преодоления защиты, создаваемой противогазами и средствами защиты кожи, химическое оружие применялось массированно, на поле боя создавались максимально возможные концентрации OB;

принцип внезапности - облако паров OB должно было быть создано в кратчайшие сроки, чтобы солдаты противника не успели надеть противогазы;

принцип преодоления противогазов противника - применение ОВ, обладающего способностью проникать через противогаз (диспергированные арсины), или применение ОВ, способного действовать на кожные покровы «в обход» противогаза (иприт, люизит);

приниип применения новых ОВ - опыт боевых действий с применением химического оружия показал, что вновь появляющиеся на фронте ОВ каждый раз вызывали у противника чувство неуверенности в надежности собственных противогазов, что приводило к ослаблению стойкости и боеспособности даже закаленных в боях частей; приниии массового воздействия $О В$ - поражающее действие облака паров ОВ пропорционально его размерам, потери противника тем выше, чем это облако шире по фронту (подавление флангового огня противника на участке прорыва) и чем оно глубже проникает в оборону противника (сковывание резервов, поражение артиллерийских батарей и штабов) $[6,7]$.

Последний принцип лежит в основе понятия оружие массового поражения. В соответствии с ним велась разработка химических боеприпасов и средств их применения, которые должны были обеспечивать распространение облака ОВ на как можно большие площади. После Первой мировой войны приоритетным у разработчиков химического оружия стали авиационные и ракетные кассетные химические боеприпасы, а также различные многоствольные системы (например, 15-см германский шестиствольный реактивный миномет Небельверфер) или системы залпового огня (например, американские залповые системы M91 для 115-мм химических ракет M55, снаряженных зарином или VX) [9, 10].

К началу 1960-х гг., благодаря развитию авиации и ракетной техники, а также принятию на вооружение фосфорорганических ОВ нервнопаралитического действия (ФОВ), химическое оружие находилось в «зените» своего развития. Появилось новое направление в создании химических боеприпасов - бинарные химические боеприпасы. В этих боеприпасах токсичные химикаты синтезируются из отделенных друг от друга прекурсоров.

Химические боеприпасы и средства их применения - это высокотехнологичное оружие. Они имеют сложную и тщательно продуманную конструкцию, позволяющую им при соответствующих средствах доставки и тактике применения поражать живую силу противника на обширных площадях. На рисунках 2-4 представлены образцы американских химических боеприпасов 1960-х гг.

На пути дальнейшего развития химического оружия появились препятствия, которые не сразу были распознаны. В последующие 40 лет после принятия на вооружение западными странами ФОВ, новых ОВ, которые по токсичности превосходили бы уже имеющиеся и при этом обладали бы оптимальными для использования в боеприпасах физико-химическими свойствами, синтезировано не было. Бинарные боеприпасы оказались слишком дорогими и сложными в производстве, имели меньшую (по сравнению с обычными химическими боеприпасами) «полезную массу». Химическое оружие достигло предела в своем развитии [12].

\footnotetext{
$\overline{2}$ Русская армия впервые применила химические снаряды 21 марта 1916 г. во время операции под Нарочью [8]. 
В.А. Ковтун, Д.П. Колесников, М.В. Супотницкий, Н.И. Шило

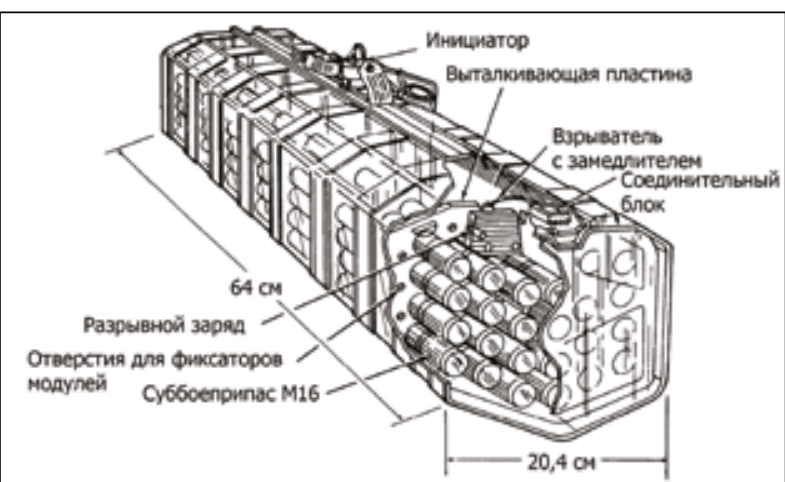

Рисунок 2 - Авиационный кассетный химический 5-фунтовый боеприпас M158. Содержит 8 пластиковых модулей, герметично соединенных друг с другом вдоль направляющего стержня. Каждый модуль содержит 33 субэлемента М16. Субэлементы снаряжены ОВ (в описании - CS), пиротехническим составом и взрывателем. Кассета сбрасывается с самолета и приводится в действие на высоте 600 футов над землей, модули выталкиваются из кассеты горящим пиротехническим составом с интервалом $0,5 \mathrm{c} \mathrm{u}$ распадаются, затем срабатывают взрыватели термогенераторов субэлементов. Площадь химического поражения одним таким кассетным боеприпасом может достигать 10 mblc. $M^{2}[11]$

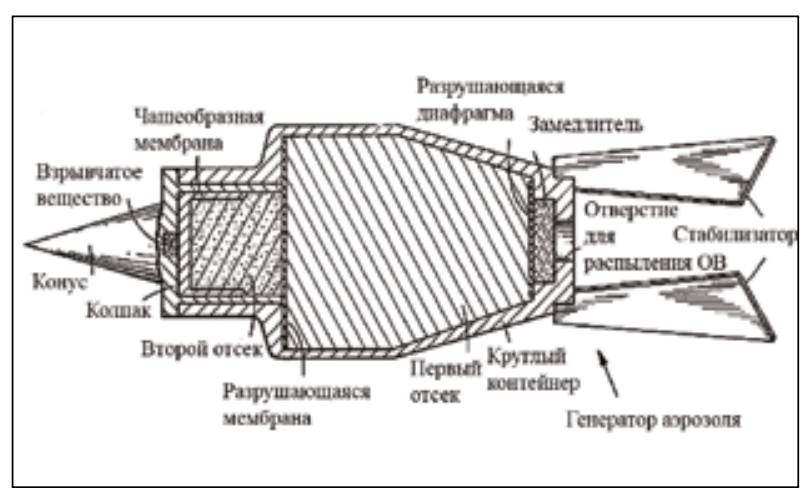

Рисунок 3 - Принципиальная схема бинарного химического боеприпаса, разработанного в США в 1960-х г2. Прекурсоры для синтеза VX находятся в двух отдельных контейнерах. Взрывной заряд минимален, он предназначен только для разрушения мембраны, разделяющей эти контейнеры. В результате экзотермической реакции, развивающейся при взаимодействии прекурсоров, синтезируется VX. Фреон, находящийся в одном из контейнеров, под воздействием температуры расширяется, повышая давление в боеприпасе. Одновременно он удерживает температуру, близкую к температуре кипения $V X\left(298^{\circ} \mathrm{C}\right)$ и снижает вязкость синтезируемого $O B$, что позволяет диспергировать синтезированное ОВ без разложения при давлении 100-400 фунтов/Дюйм² [14]

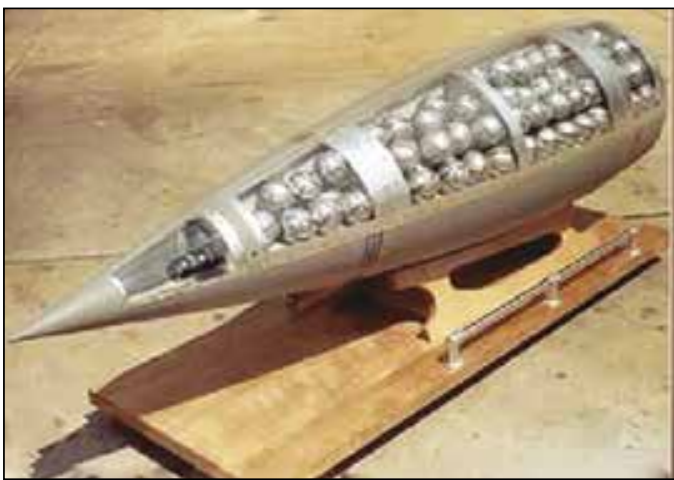

A

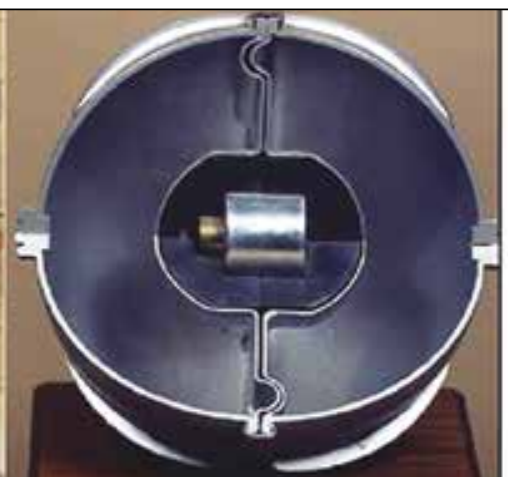

Б

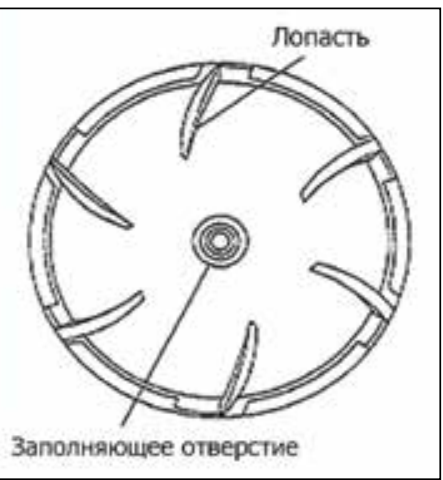

B

Рисунок 4 - Химические боеприпасы, доставляемые к цели баллистическими ракетами

(А. Боевая часть химической неуправляемой ракеты средней дальности M190 Honest John, снаряженная сферическими саморассеивающимися бомбами малого калибра М139. Б. Химическая бомба малого калибра М139 для снаряжения ракет M206 Little John (дальность до 19 кM), M190 Honest John (до 33 кM) и M212 Sergeant (до 139 км). Диаметр бомбы - 4,5 дюйма. Состояла из двух половинок, снаряженных зарином. Разрывной заряд расположен в чентре бомбы. В. Конфигурация поверхности бомбы М139 обеспечивала ей вращение вокруг своей оси по принципу юлы. При определенном количестве оборотов приводился в действие взрыватель, обеспечивающий подрыв химического боеприпаса на заданной высоте [9, 13])

Кроме того, с 1915 г. изменились подходы к ведению боевых действий. В конце XX в. они приобрели ярко выраженный характер воздушно-наземных операций. Государства, обладающие высокими технологиями, стали заложниками ими же созданных мифов о высокотехнологичной войне, возможности решения всех боевых задач высокоточным оружием, профессиональной армией, искусственным интеллектом, беспилотными летальными аппаратами, боевыми роботами и т.п., и постепенно утрачивали интерес к химическому оружию. В 1993 г. была подписана КХO, предполагавшая полное химическое разоружение ее участников. Химическое оружие переместилось в нишу террористи- 
Сирийская «химическая война»

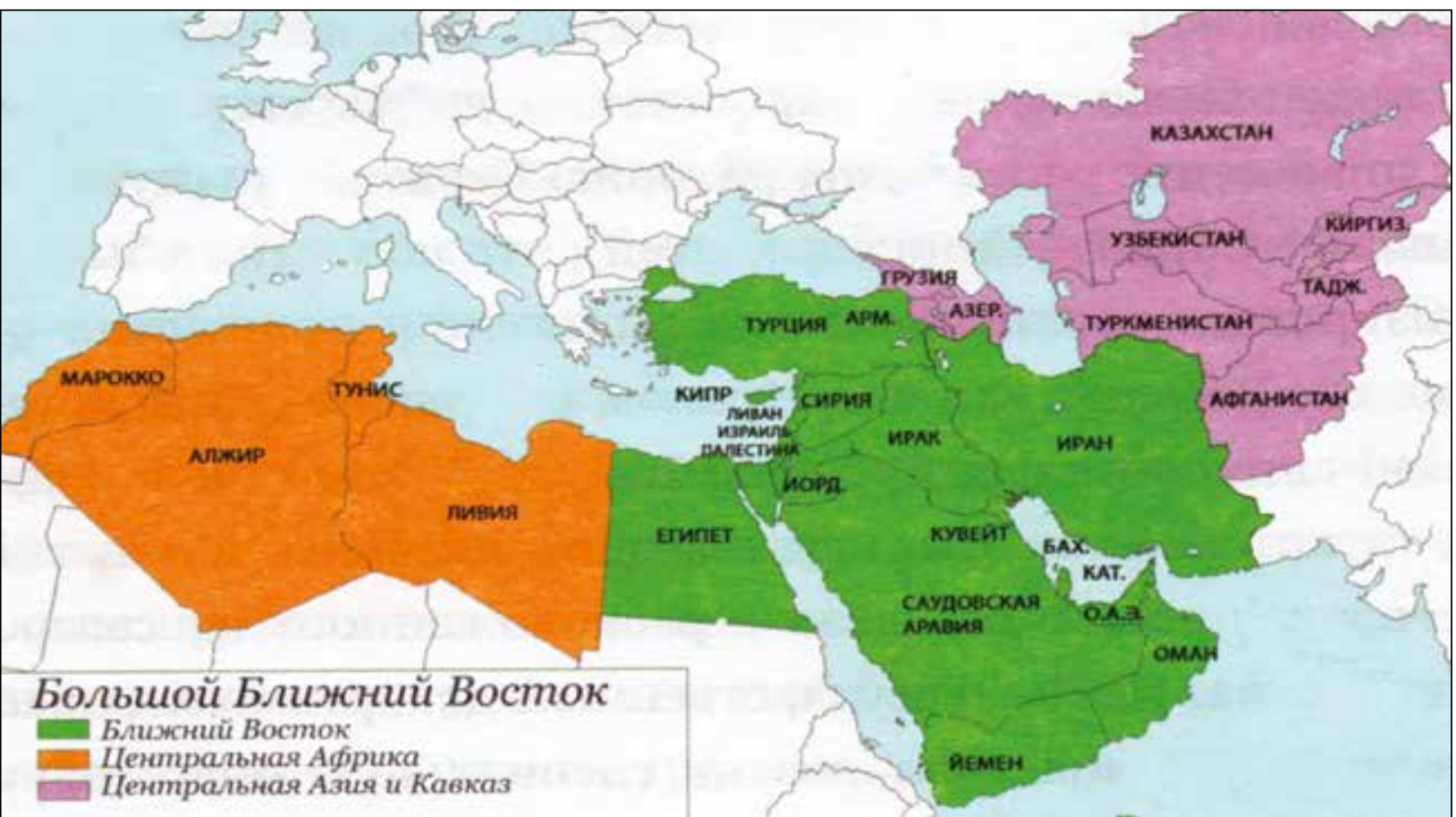

Рисунок 5 - Большой Ближний Восток. Термин появился во времена администрации Буша-Чейни (2001-2009 г2.). Он обозначает проект, названный в 2011 г. «Арабской весной». Он предполагает «демократизацию» режимов в мусульманских странах приходом к власти «Братьев-мусульман». Схема проста и однообразна в применении к самым разным странам: МВФ требует от властей снижения социальных расходов, приватизации и жесткой экономии, которые предсказуемо вызывают разрушение экономики страны, массовое обнищание и недовольство населения. Потом провокаторы начинают через СМИ и социальные сети активно призывать к массовым протестам молодежь, появляются картинки с «жертвами режима» и т.д. Показательно, что Армения и Казахстан также входят в «проект» Большой Ближний Восток [19]

ческих группировок, спонсируемых в том числе и западными спецслужбами.

События, предшествовавшие химической войне в Сирии. Опыт итальяно-эфиопской войны 1935-1936 гг. свидетельствует, что в условиях реального применения химического оружия подготовленными армейскими частями «повстанческая война» невозможна в принципе [15]. Тогда возникает вопрос, почему химическое оружие в Сирии применяется не так, как требуют боевые наставления, например, «Наставление по боевому применению химического и биологического оружия армии США» (FM 3-10) $)^{3}$. Обратимся к истории конфликта.

В качестве очевидных предпосылок к гражданской войне в Сирии обычно указывают на засуху 2007 г. и связанные с ней ошибки правительства, приведшие к внутренней миграции населения, безработице, обнищанию народа и антиправительственным выступлениям. И якобы эскалация насилия со стороны властей привела к вооруженным выступлениям граждан ${ }^{4}$. Эта версия удобна для тех, кто в очередной раз освобождает страну от «тирана». Но она не объясняет, почему население бежит от «освободителей» под защиту к тому же «тирану» и в Европу, а сами «освободители» на «освобожденных территориях» узаконивают рабство, последовательно уничтожают промышленность, сельское хозяйство, торговлю, городскую инфраструктуру, административные, научные и образовательные учреждения и людей.

Обратимся к хронологии событий, предшествовавших применению химического оружия в сирийской войне, обобщенных французским исследователем Thierry Meyssan [17].

2001 г.:

конец сентября - совещание в Кемп-Девиде под председательством президента США Дж. Буша, где как принцип ведения войны было принято решение о разрушении всех на то время не контролируемых ад-

\footnotetext{
Наставление определяет типы и расход химических и биологических боеприпасов, средства и способы их применения в зависимости от площади, формы целей, защищенности личного состава и т.п. [16].

4 Гражданская война в Сирии. URL: http://ru.wikipedia.nom.cl/wiki/ Гражданская_война в_Сирии \# Начало_ гражданских_протестов (дата обращения: 20.07.2018 г.).
} 
министрацией США стран на Большом Ближнем Востоке. Этот проект директор ЦРУ Дж. Теннет назвал «Матрицей мирового наступления». Историческим фоном данного решения стали: события 11 сентября того же года, заказчик которых не установлен до сих пор; ложное убеждение в наступившем «конце истории» ${ }^{5}$, подразумевавшем вечное глобальное доминирование США и стран Запада; оказавшийся ложным страх скорого исчерпания разведанных мировых запасов нефти (рисунок 5).

\section{2 г.:}

август - Британская разведка Ми-6 проводит в Лондоне конференцию «Братьев-мусульман» на тему «Сирия для всех» с основной мыслью, что «Сирия стонет под игом секты алавитов и только «Братья-мусульмане» способны принести ей подлинную свободу; письмо американского президента Дж. Буша сирийскому и ливийскому лидерам с требованием «или объявить о полном роспуске армий, или быть готовым к их разоружению и всеобщему разрушению Соединенными Штатами без обсуждения». 2003 г.:

12 декабря - президент США Дж. Буш ратифицировал «Закон об ответственности Сирии», составленный по образцу «Закона об освобождении Ирака» 1998 г.

2004 г.:

конец года - из-за неудач операции в Ираке США принимают британский план по свержению светских режимов на всем Большом Ближнем Востоке и по переделу региона, находящегося еще в старых колониальных границах 6 , на маленькие (не более 10 млн человек), этнически однородные государства под управлением «Братьев-мусульман», опустив их население до состояния, когда «человек человеку волк». Этот план представляет собой возвращение к сформировавшейся в конце XIX в. среди британской политической элиты идее «неформальной империи», закреплявшей глобальное господство англосаксонского мира без содержания дорогостоящих оккупационных армий [20].

\section{6 г.:}

1 августа - британский премьер-министр Тони Блэр на Мировом деловом совете в Лос-Анджелесе призвал коллег поддержать «Братьев-мусульман» в борьбе против экстремистов и за демократию;

ноябрь - президент Сирии Башар Асад отверг ультиматум Евросоюза с требованиями либерализации экономики в ущерб населению Сирии и признания утраты Голанских высот;

в этом же году Ми-6 приступила к подготовке «Арабской весны», Франция предложила Турции присоединиться к операциям, которые она вместе с Великобританией готовила против Ливии и Сирии. Заключено тайное соглашение, предполагающее использование против правительственных сил Сирии сирийского туркменского меньшинства (туркоманов) в обмен на решение «курдского вопроса» за счет территории Сирии.

2010 г.:

3-е ноября - Николя Саркози и Дэвид Кэмерон подписывают Договор об объединении усилий в области безопасности. На 15-25 марта 2011 г. намечены крупные совместные учения британо-французских сил, в рамках которых 21 марта 2011 г. предполагалось нападение на Сирию, но 19 марта 2011 г. Саркози отменил сирийское направление, решив сосредоточиться только на Ливии.

\section{1 г.:}

4-е февраля - призывы к антиправительственным выступлениям в Дамаске не дали результатов;

18-е марта - нападение джихадистов на центр специальных служб в проправительственном городе Дераа. Центр использовался исключительно для отслеживания активности Израиля на Голанских высотах. В городе начались кровавые столкновения. Большая часть убитых - полицейские и военные;

5-е сентября - Николя Саркози принял патриарха сирийских маронитов и заявил ему, что союзники хотят привести к власти в Дамаске «Братьев-мусульман»;

\footnotetext{
5 Часть названия книги американского философа Фрэнсиса Фукуямы «Конец истории и последний человек» [18] - идеологической платформы нового видения мира как либеральной демократии западного образца. Она стала «каноническим текстом» американских неоконсерваторов вроде Дж. Буша-младшего, оправдывала цели их внешней политики - активное продвижение «демократии» западного стиля и «свободного рынка» по всему миру.

6 Современные границы ближневосточных стран в основном соответствуют тем, что произвольно определены в феврале 1916 г. секретным британо-французским планом Сайкса-Пико. План предполагал распределение соответствующих частей Османской империи между державами-победительницами с формированием на этих территориях государств-протекторатов. Новый передел этих же территорий учитывает «конец истории», т.е. новую геополитическую реальность, сложившуюся после прекращения существования СССР и предполагаемого вечного доминирования Запада [20].

7 «Братья-мусульмане» - международная религиозно-политическая ассоциация, прикрывающая свои политические цели религиозными терминами. Основана в Египте в марте 1928 г. учителем Хасаном аль-Банной. Во время Второй мировой войны «Братья» сотрудничали с Германией. После завершения войны британская секретная служба Ми-6 вскрыла сеть «Братьев» в Египте и предложила им новую работу - разрушение молодого израильского государства. В дальнейшем их использовали ЦРУ и Ми-6 против СССР и неугодных режимов на Ближнем Востоке и в Центральной Азии - более подробно см. в работах Th. Meyssan [17] и W. Engdahl [20].
} 
20-е октября - убийство Муамара Каддафи ${ }^{8}$; ноябрь - перевозка на корабле 1200 джихадистов из Ливии в Турцию. Они составили первые отряды Сирийской свободной армии. Общее количество джихадистов в Сирии и Ираке - не менее 350 тыс. бойцов, что в два раза превосходит численность сирийской армии.

2012 г.:

1 апреля - по инициативе США и Франции создана группа «Друзья Сирии», предназначенная для обсуждения ситуации в Сирии за пределами Совета Безопасности ООН. «Друзья Сирии» понадобились США как ответ на вето России и Китая, наложенное на резолюцию Совета Безопасности, осуждающую Сирию. В группу вошли 70 стран. Им обещаны концессии на распоряжение сирийским газом в обмен на поддержку свержения Асада, т.е. Сирию предложено рассматривать как «добычу для шакалов»;

1 апреля - создан «Сирийский институт правосудия и ответственности» (SJAC), представляющий собой агентство по фабрикации доказательств виновности сирийского правительства в вымышленных преступлениях. «Институт» зарегистрирован как неправительственная организация в Нидерландах и в США, финансируется странами коалиции. В действительности эта неправительственная организация - приращение к «Бюро за глобальную юстицию» Госдепартамента США. Теперь все готово для начала большой войны;

12 июля - стартовала операция «Дамасский вулкан и сирийское землетрясение» ${ }^{9}$. Более 40 тыс. наемников, наспех собранных из арабских стран, Пакистана и Афганистана, оплаченных саудитами, перешли сирийско-иорданскую границу и начали наступление на Дамаск;

18 июля - бомбой, сброшенной с беспилотника неустановленной принадлежности, взорван офис Национального совета по безопасности в Дамаске, погибли министр обороны, руководители военной разведки и контрразведки и высокопоставленные силовики. Сирийская армия обезглавлена. Резня на улицах Дамаска. Нападавшим были даны координаты конкретных целей и адреса устраняемых людей, однако сирийская армия смогла отбить это нападение;

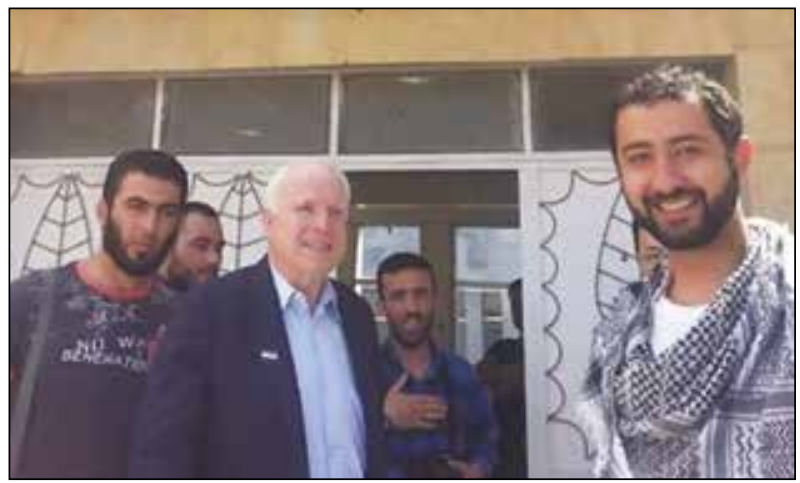

Рисунок 6 - Сенатор Джон Маккейн с главарями исламистских боевиков в Сирии в мае 2013 г. На фотографии Мухаммад Нур (в проеме двери), ведущий член бригады «Северная буря» (часть ан-Нусры, то есть сирийской Аль-Каиды), захватившей 11 ливийских паломников-шиитов в Аазазе. Когда сенатору стали задавать неудобные вопросы относительно его контактов с таким человеком, Маккейн ответил, что знать его не знает и не понимает, как тот попал в кадр

17 августа - министр иностранных дел Франции Лоран Фабиус заявил, что Асад «не заслужил права жить».

2013 г.:

январь - Ми-6 создает неправительственную добровольческую организацию «Белые каски» (White Helmets, Syria Civil Defence, SCD), предназначенную для ведения пропагандистской деятельности против законного правительства Сирии и легализации деятельности западных спецслужб в Сирии на территориях, контролируемых оппозиционными группировками. Их крупнейший донор Агентство международного развития США (US Agency for International Development, USAID);

19 марта - применение джихадистами зарина в пригороде Алеппо;

23 мая - турецкая полиция арестовала в Адане 11 джихадистов (1 сириец, 10 турок), у которых найдены емкости с большим количеством зарина;

май - сенатор Маккейн посещает территории Сирии, захваченные ИГИЛ ${ }^{10}$ (рисунок 6) ${ }^{11}$;

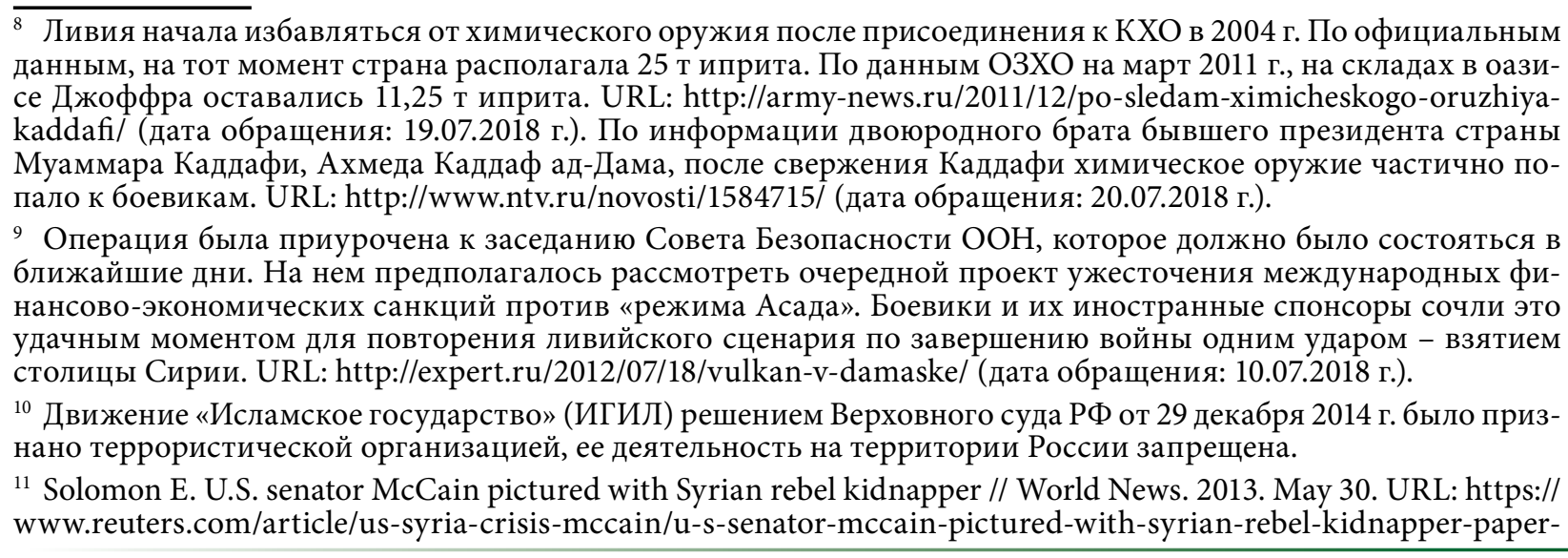


21 августа - химическая атака в Гуте.

Даже эти фрагментарные сведения о событиях, предшествовавших применению химического оружия в сирийской войне, говорят о том, что Сирия была обречена на уничтожение уже с 2002 г. Подлинные цели войны состоят в расчленении крупных государств Большого Ближнего Востока, в грабеже их территорий и уничтожении их государственной инфраструктуры, Сирия - лишь этап этой войны, химическая война в Сирии - один из ее инструментов.

Хронология химической войны в Сирии. Химическая война в Сирии началась 19 марта 2013 г. с запуска антиправительственными силами ракеты, снаряженной зарином, по району Хан аль-Асаль под Алеппо, контролируемому правительством. Правительство САР сразу же обратилось к ООН с просьбой о помощи в расследовании обстоятельств применения в этом городе химического оружия и о направлении чрезвычайной миссии, которая могла бы оказать сирийскому правительству поддержку в деле расследования обстоятельств применения токсичных химических веществ и установления личности тех, кто их применил ${ }^{12}$.

Никто из западных политиков не осудил это преступление. А 5 апреля министр обороны США Чак Хейгел заявил, что власти Сирии, вероятно, применяли химическое оружие. По его словам, к таким выводам пришла американская разведка. Полной уверенности на этот счет у американских спецслужб нет, но все же они полагают, что правительство Башара Асада прибегало к использованию химического оружия, в частности, зарина. Госсекретарь Джон Керри также заявил, что правительственные силы как минимум в двух атаках применили химическое оружие. Белый дом проинформировал членов американского Конгресса. Таким образом, первое применение химического оружия на территории Сирии получило полную поддержку со стороны США и их союзников. Дальнейшие события химической войны в Сирии кратко обобщены в таблице 1.

Теперь более обстоятельно рассмотрим эпизоды применения химического оружия в Сирии, привлекшие к себе внимание «мирового сообщества», ООН и О3ХО.

Химический инцидент 21 августа 2013 г. в пригороде Дамаска Восточная Гута. В ин- формационном пространстве этот эпизод химической войны в Сирии был представлен наиболее зрелищно и трагично. Расследование инцидента проводилось специальной миссией Организации Объединенных Наций. По результатам расследования был подготовлен доклад A/67/997S/2013/553 $3^{13}$, вызвавший много вопросов у российских специалистов. Все расследование специальной миссии свелось к попытке обоснования того, что правительство Сирии применило не менее 8 ракет с зарином «против своего народа», что привело к массовой гибели людей в пригороде Дамаска. В качестве доказательства «преступления режима» были продемонстрированы фрагменты ракет и многочисленные видео и фотоматериалы с пострадавшими и погибшими детьми.

В докладе никак не объяснен факт отсутствия зарина в пробах, взятых на шестой день после предполагаемого применения химического оружия и внезапное появление чистого зарина в пробах, взятых двумя днями позже. Не объяснен тот факт, что посторонние лица, переносившие подозрительные боеприпасы и фрагменты доказательств (которые были заражены ОВ) с места на место, не получили токсических поражений.

Неясно и то, насколько материальные объекты (включая фрагменты боеприпасов), с которых были взяты пробы на шестой, восьмой и девятый дни после предполагаемого применения химического оружия, вообще имеют отношение к местам предполагаемого применения и присутствовали они там в это время, или нет. Так как, по данным доклада, места происшествий не были изолированы от посторонних лиц как до, так и во время обследования, а пробы с мест событий брались на шестой, восьмой и девятый дни после предполагаемого использования химического оружия, напрашивается простое объяснение не объясненным в докладе специальной миссии фактам - фрагменты и «доказательства» могли быть обработаны ОВ и (или) доставлены в указанные места «заинтересованными лицами» перед прибытием следственной группы.

Теперь рассмотрим обломки неуправляемых реактивных снарядов, детали которых обследовали инспекторы специальной миссии в качестве доказательства «преступления режима». Изображенная на фотографии (с. 19

idUSBRE94T0V320130530 (дата обращения: 11.07.2018 г.). Мейсан Т. Джон Маккейн и Халиф Ибрагим. Как хорошая сирийская оппозиция превратилась в злых боевиков Ирака // Однако. 2014. 18 августа. URL: http:// www.odnako.org/blogs/dzhon-makkeyn-i-halif-ibragim-kak-horoshaya-siriyskaya-oppoziciya-prevratilas-v-zlih-boevikov-iraka/ (дата обращения: 10.07.2018 г.)

12 Джаафари Башар. Роль иностранных держав в использовании химического оружия против Cирии. URL: http://www.voltairenet.org/article201878.html (дата обращения: 20.07.2018 г.).

${ }^{13}$ Report of the United Nations mission to investigate allegations of the use of chemical weapons in the Syrian Arab Republic on the alleged use of chemical weapons in the Ghouta area of Damascus on 21 August 2013. URL: http:// www.2013securitycouncilreport.orgratf...6D27...s_2013_553.pdf (дата обращения: 10.07.2018 г.). 
Таблица 1 - Основные события «химической войны» в Сирии*

\begin{tabular}{|c|c|c|c|c|c|}
\hline $\begin{array}{l}\text { Дата и } \\
\text { место }\end{array}$ & $\begin{array}{c}\text { Масштаб } \\
\text { применения } \\
\text { (предполагае- } \\
\text { мое ОВ) }\end{array}$ & $\begin{array}{l}\text { Контекст боевых } \\
\text { действий в Сирии }\end{array}$ & $\begin{array}{c}\text { Источники } \\
\text { сведений о } \\
\text { применении } \\
\text { химического } \\
\text { оружия }\end{array}$ & $\begin{array}{c}\text { Международная } \\
\text { реакция }\end{array}$ & $\begin{array}{c}\text { Позиция } \\
\text { ОзХО }\end{array}$ \\
\hline $\begin{array}{c}19.03 . \\
2013 \text { г., } \\
\text { район Алеппо }\end{array}$ & $\begin{array}{c}\text { Единичная ракета, } \\
16 \text { погибших со } \\
\text { стороны прави- } \\
\text { тельственных сил } \\
\text { (зарин) }\end{array}$ & $\begin{array}{c}\text { Осада } \\
\text { антиправительст- } \\
\text { венными силами } \\
\text { пригородов Дамаска и } \\
\text { Алеппо }\end{array}$ & $\begin{array}{c}\text { Правительство } \\
\text { Сирии }\end{array}$ & $\begin{array}{c}\text { Сначала игнори- } \\
\text { рование заявления } \\
\text { правительства Сирии, } \\
\text { потом поддержка } \\
\text { джихадистов: } 25 \\
\text { апреля министр обо- } \\
\text { роны США заявил, } \\
\text { что власти Сирии, } \\
\text { вероятно, применяли } \\
\text { химическое оружие. } \\
\text { В июне Белый дом } \\
\text { заявил, что силы си- } \\
\text { рийского президента } \\
\text { пересекли «красную } \\
\text { линию», используя } \\
\text { химическое оружие, } \\
\text { в том числе газ зарин, } \\
\text { против повстанческих } \\
\text { сил. Это побудило } \\
\text { правительство США } \\
\text { начать оказывать } \\
\text { военную поддержку } \\
\text { силам оппозиции, } \\
\text { несмотря на то, что } \\
\text { ранее оно не желало } \\
\text { этого делать }\end{array}$ & $\begin{array}{c}\text { Представители } \\
\text { ОЗХО, несмотря } \\
\text { на неоднократ- } \\
\text { ные просьбы } \\
\text { сирийского пра- } \\
\text { вительства, не } \\
\text { посещали район } \\
\text { химической } \\
\text { атаки }\end{array}$ \\
\hline $\begin{array}{c}21.08 .2013 \text { г., } \\
\text { пригород Да- } \\
\text { маска - Вос- } \\
\text { точная Гута }\end{array}$ & $\begin{array}{c}\text { Не менее } 8 \text { само- } \\
\text { дельных ракет. } \\
\text { Количество по- } \\
\text { гибших называют } \\
\text { по принципу «кто } \\
\text { больше» - от } 47 \\
\text { до 1400. Мишенью } \\
\text { для ракет было на- } \\
\text { селение пригорода } \\
\text { (зарин) }\end{array}$ & $\begin{array}{c}\text { Накануне нападения } \\
\text { Франция, США при } \\
\text { поддержке ряда араб- } \\
\text { ских стран рассмат- } \\
\text { ривали возможность } \\
\text { нанесения ударов по } \\
\text { Сирии }\end{array}$ & $\begin{array}{c}\text { Сирийская сво- } \\
\text { бодная армия, } \\
\text { «Врачи без гра- } \\
\text { ниц» }\end{array}$ & $\begin{array}{c}\text { Для обоснования } \\
\text { вторжения западной } \\
\text { коалиции было ис- } \\
\text { пользовано массовое } \\
\text { убийство детей для } \\
\text { создания видеома- } \\
\text { териалов о якобы } \\
\text { жертвах химического } \\
\text { оружия Асада. Но на } \\
\text { резолюцию запад- } \\
\text { ных стран в Совете } \\
\text { Безопасности о не- } \\
\text { обходимом вмеша- } \\
\text { тельстве «междуна- } \\
\text { родного сообщества» } \\
\text { в ситуацию в Сирии, } \\
\text { Россия и Китай нало- } \\
\text { жили } 29 \text { августа вето }\end{array}$ & $\begin{array}{c}\text { Подготовлен } \\
\text { доклад Мис- } \\
\text { сией ООН по } \\
\text { расследованию } \\
\text { сообщений о } \\
\text { применении } \\
\text { химического } \\
\text { оружия }\end{array}$ \\
\hline $\begin{array}{c}\text { Апрель -ав- } \\
\text { густ } 2014 \text { г., } \\
\text { северная Си- } \\
\text { рия. Провин- } \\
\text { ция Идлиб. } \\
\text { Населенные } \\
\text { пункты Таль- } \\
\text { менес (21 и } \\
24 \text { апреля), } \\
\text { ат-Тамана, } \\
\text { Кафр Зейта }\end{array}$ & $\begin{array}{c}\text { Единичные бочко- } \\
\text { вые бомбы кустар- } \\
\text { ного производства } \\
\text { с баллонами хлора } \\
\text { внутри (!?); } 21 \text { ин- } \\
\text { цидент, } 13 \text { погиб- } \\
\text { ших, все мирные } \\
\text { жители }\end{array}$ & $\begin{array}{c}\text { Наступление терро- } \\
\text { ристических органи- } \\
\text { заций Фронт Нусра, } \\
\text { Ахрар аш-Шам и еще } \\
\text { нескольких местных } \\
\text { банд, контролиру- } \\
\text { ющих Тальменес на } \\
\text { линии коммуникаций } \\
\text { двух баз ВВС Сирии: в } \\
\text { Вади Дейфе и аль-Ха- } \\
\text { мади }\end{array}$ & $\begin{array}{c}\text { Западные СМИ } \\
\text { и свидетели }\end{array}$ & $\begin{array}{c}\text { Западные лидеры } \\
\text { возложили вину за } \\
\text { применение само- } \\
\text { дельных боепри- } \\
\text { пасов с хлором на } \\
\text { правительство Сирии }\end{array}$ & $\begin{array}{c}\text { Генеральный } \\
\text { директор ОЗХО } \\
\text { Ахмет Узюм- } \\
\text { джю (Ahmet } \\
\text { Uzumcu) в апре- } \\
\text { ле } 2014 \text { г. соз- } \\
\text { дает Миссию по } \\
\text { установлению } \\
\text { фактов (МУФ) } \\
\text { использования } \\
\text { хлора в качестве } \\
\text { оружия в Сирии }\end{array}$ \\
\hline
\end{tabular}


Продолжение таблицы 1

\begin{tabular}{|c|c|c|c|c|c|}
\hline $\begin{array}{l}\text { Дата и } \\
\text { место }\end{array}$ & $\begin{array}{c}\text { Масштаб при- } \\
\text { менения (пред- } \\
\text { полагаемое ОВ) }\end{array}$ & $\begin{array}{l}\text { Контекст боевых } \\
\text { действий в Сирии }\end{array}$ & $\begin{array}{c}\text { Источники } \\
\text { сведений о } \\
\text { применении } \\
\text { химического } \\
\text { оружия }\end{array}$ & $\begin{array}{c}\text { Международная } \\
\text { реакция }\end{array}$ & $\begin{array}{c}\text { Позиция } \\
\text { ОЗХО }\end{array}$ \\
\hline $\begin{array}{c}\text { С } 16 \text { марта } \\
\text { по } 20 \text { мая } \\
2015 \text { г., Кме- } \\
\text { нас, провин- } \\
\text { ция Идлиб }\end{array}$ & $\begin{array}{c}5 \text { «ударов», Пер- } \\
\text { вый - } 16 \text { марта. По } \\
\text { словам очевидцев, } \\
\text { вертолет сбросил } \\
\text { две «бочковые } \\
\text { бомбы» или два } \\
\text { предмета, похо- } \\
\text { жих на бочки. Все- } \\
\text { го } 60 \text { пострадав- } \\
\text { ших (почувство- } \\
\text { вали запах хлора } \\
\text { или чистящего } \\
\text { средства), жалобы } \\
\text { на удушье. Все } \\
\text { пострадавшие - } \\
\text { гражданские лица, } \\
\text { погибших нет }\end{array}$ & $\begin{array}{c}\text { Кменас служил одной } \\
\text { из баз для наступле- } \\
\text { ния банд на Идлиб, } \\
\text { контролируемый тог- } \\
\text { да правительственны- } \\
\text { ми войсками. } 28 \text { марта } \\
\text { Идлиб был взят анти- } \\
\text { правительственными } \\
\text { силами }\end{array}$ & $\begin{array}{c}\text { Очевидцы и } \\
\text { НПО. Пробы } \\
\text { и другие «до- } \\
\text { казательства» } \\
\text { переданы } \\
\text { МУФ неправи- } \\
\text { тельственной } \\
\text { организацией } \\
\text { «Сирийский } \\
\text { центр доку- } \\
\text { ментирования } \\
\text { химических } \\
\text { нарушений» } \\
\text { (CVDCS) }\end{array}$ & $\begin{array}{c}\text { Эта атака нашла свое } \\
\text { отражение в докладе } \\
\text { СМР Совету Безопас- } \\
\text { ности ООН. } \\
\text { В нем говорится, что } \\
\text { сирийская армия } \\
\text { применяла запре- } \\
\text { щенное оружие - } \\
\text { бочковые бомбы } \\
\text { с газообразным } \\
\text { хлором, которые } \\
\text { сбрасывались с вер- } \\
\text { толетов. В докладе } \\
\text { говорится, что по- } \\
\text { леты совершались } \\
\text { с двух баз, где были } \\
\text { дислоцированы 253-я } \\
\text { и 255-я эскадрильи } \\
\text { б3-й вертолетной } \\
\text { бригады. } \\
\text { Обвинение в атаке в } \\
\text { Кменасе стало уже } \\
\text { третьим, выдвину- } \\
\text { тым СМР против } \\
\text { Дамаска. В преды-- } \\
\text { дущем докладе, } \\
\text { представленном в } \\
\text { августе, правитель- } \\
\text { ственные войска } \\
\text { были обвинены в } \\
\text { применении хлора } \\
16 \text { марта 2015 г. в } \\
\text { Сармине и 21 апреля } \\
\text { 2014 г. - в Тальме- } \\
\text { несе }\end{array}$ & $\begin{array}{c}\text { Миссии ОЗХО } \\
\text { не удалось } \\
\text { получить од- } \\
\text { нозначных и } \\
\text { убедительных } \\
\text { доказательств } \\
\text { применения хи- } \\
\text { мического ору- } \\
\text { жия сирийской } \\
\text { армией, однако } \\
\text { в отчете Мис- } \\
\text { сии высказано } \\
\text { предположение } \\
\text { о вероятном } \\
\text { применении } \\
\text { «бинарного } \\
\text { химического } \\
\text { оружия», якобы } \\
\text { состоящего из } \\
\text { двух сосудов, } \\
\text { при взаимодей- } \\
\text { ствии компо- } \\
\text { нентов которых } \\
\text { выделяется } \\
\text { хлор. При всей } \\
\text { нелепости дан- } \\
\text { ного предполо- } \\
\text { жения, сделаны } \\
\text { далеко идущие } \\
\text { выводы }\end{array}$ \\
\hline $\begin{array}{c}16 \text { сентября } \\
2016 \text { г. } \\
\text { Применение } \\
\text { боевиками } \\
\text { двух мин с } \\
\text { ипритом по } \\
\text { населенному } \\
\text { пункту Ма- } \\
\text { рат-Умм-Хауш, } \\
40 \text { постра- } \\
\text { давших. Одна } \\
\text { мина не разо- } \\
\text { рвалась }\end{array}$ & $\begin{array}{c}\text { Найдена самодель- } \\
\text { ная 240-мм мина } \\
\text { с заливной горло- } \\
\text { виной в хвостовой } \\
\text { части. Внутри нахо- } \\
\text { дилась черная мас- } \\
\text { лянистая жидкость } \\
\text { объемом 0,5-1,5 л. } \\
\text { По данным специ- } \\
\text { алистов войск РХБ } \\
\text { защиты, мина была } \\
\text { снаряжена } \\
\text { сернистым ипритом }\end{array}$ & $\begin{array}{c}\text { Постоянные обстрелы } \\
\text { из минометов городов } \\
\text { и населенных пунктов, } \\
\text { находящихся под конт- } \\
\text { ролем правительства } \\
\text { САР }\end{array}$ & $\begin{array}{c}\text { Правительство } \\
\text { САР }\end{array}$ & $\begin{array}{c}\text { Реакции не } \\
\text { последовало }\end{array}$ & $\begin{array}{c}\text { Миссия ОЗХО } \\
\text { признала факт } \\
\text { химического } \\
\text { нападения на } \\
\text { Марат-Умм- } \\
\text { Хауш. По дан- } \\
\text { ным миссии, его } \\
\text { осуществили } \\
\text { боевики тер- } \\
\text { рористической } \\
\text { группировки } \\
\text { «Исамское го- } \\
\text { сударство» }\end{array}$ \\
\hline
\end{tabular}




\begin{tabular}{|c|c|c|c|c|c|}
\hline $\begin{array}{l}\text { Дата и } \\
\text { место }\end{array}$ & $\begin{array}{l}\text { Масштаб при- } \\
\text { менения (пред- } \\
\text { полагаемое ОВ) }\end{array}$ & $\begin{array}{l}\text { Контекст боевых } \\
\text { действий в Сирии }\end{array}$ & $\begin{array}{c}\text { Источники } \\
\text { сведений о } \\
\text { применении } \\
\text { химического } \\
\text { оружия }\end{array}$ & $\begin{array}{c}\text { Международная } \\
\text { реакция }\end{array}$ & $\begin{array}{c}\text { Позиция } \\
\text { ОзХ0 }\end{array}$ \\
\hline \begin{tabular}{|}
24 марта, \\
25 марта, \\
30 марта \\
2017 г., де- \\
ревня аль-Ла- \\
тамна в уезде \\
Махарда, \\
провинция \\
Хама
\end{tabular} & $\begin{array}{c}24 \text { марта в } 5.45 \text { - } \\
\text { взрывы на поле в } \\
\text { южной части дерев- } \\
\text { ни двух боеприпа- } \\
\text { сов, снаряженных } \\
\text { зарином, отравле- } \\
\text { ние получили } 16 \\
\text { человек; } 25 \text { марта - } \\
\text { «бочковая бомба» } \\
\text { попала в вестибюль } \\
\text { полевого госпиталя } \\
\text { боевиков, отравле- } \\
\text { ние хлором полу- } \\
\text { чили } 33 \text { человека, } \\
\text { один погиб; } \\
\text { зо марта - целью } \\
\text { химической атаки } \\
\text { были фермеры в } \\
\text { поле. } 16 \text { пострадав- } \\
\text { ших, имитация при- } \\
\text { менения боеприпа- } \\
\text { сов, снаряженных } \\
\text { зарином }\end{array}$ & \multirow{2}{*}{$\begin{array}{c}\text { Катастрофическое } \\
\text { поражение ИГИЛ под } \\
\text { Пальмирой, город взят } \\
\text { сирийскими войсками; } \\
\text { вытеснение боевиков } \\
\text { из Хомса. Начался } \\
\text { процесс нормализации } \\
\text { российско-турецких } \\
\text { отношений. Внешнепо- } \\
\text { литическая ситуация } \\
\text { последних недель } \\
\text { складывалась в пользу } \\
\text { Дамаска. } \\
\text { США кардинальным } \\
\text { образом изменили } \\
\text { свой взгляд на сирий- } \\
\text { ский конфликт. Белый } \\
\text { дом устами своего } \\
\text { пресс-секретаря зая- } \\
\text { вил, что для США в Си- } \\
\text { рии главным приори- } \\
\text { тетом является борьба } \\
\text { с ИГИЛ, а не отставка } \\
\text { президента Башара } \\
\text { Асада. Эту же позицию } \\
\text { озвучивали постпред } \\
\text { США при ООН Никки } \\
\text { Хейли и госсекретарь } \\
\text { Рекс Тиллерсон }\end{array}$} & $\begin{array}{l}\text { UOSSM USA, } \\
\text { «Белые каски» } \\
\text { (Сирийская } \\
\text { гражданская } \\
\text { оборона), } \\
\text { Сирийский } \\
\text { центр собы- } \\
\text { тий» (Syrian } \\
\text { Event Centre), } \\
\text { новостные лен- } \\
\text { ты BBC, CNN, } \\
\text { «Washington } \\
\text { Times», блоги }\end{array}$ & $\begin{array}{c}\text { СМР ООН по рассле- } \\
\text { дованию событий в } \\
\text { Сирийской Арабской } \\
\text { Республике заявил, } \\
\text { что атаку осуществи- } \\
\text { ли сирийские власти. } \\
\text { Хотя некоторые «сви- } \\
\text { детели» возлагали } \\
\text { ответственность на } \\
\text { ВКС РФ, но свиде- } \\
\text { тельств в поддержку } \\
\text { этого заявления об- } \\
\text { наружить не удалось }\end{array}$ & $\begin{array}{c}\text { Расследование } \\
\text { проводилось } \\
\text { дистанционно, } \\
\text { на основании } \\
\text { «интервью, } \\
\text { которые, где } \\
\text { возможно, } \\
\text { подтверждены } \\
\text { разными интер- } \\
\text { вьюируемыми } \\
\text { лицами». Фор- } \\
\text { мулировки вы- } \\
\text { водов - «более } \\
\text { чем вероятно», } \\
\text { «указывают на } \\
\text { вероятность» } \\
\text { и т.п. }\end{array}$ \\
\hline $\begin{array}{c}4 \text { апреля } \\
2017 \text { г., город } \\
\text { Хан-Шейхун } \\
\text { (провинция } \\
\text { Идлиб) }\end{array}$ & $\begin{array}{c}\text { По заявлению вла- } \\
\text { стей города, по- } \\
\text { гибло } 89 \text { человек, } \\
\text { пострадало более } \\
\text { 550. Имитация } \\
\text { применения пра- } \\
\text { вительственными } \\
\text { силами авиабом- } \\
\text { бы, снаряженной } \\
\text { зарином }\end{array}$ & & $\begin{array}{c}\text { Телеканалы } \\
\text { «Ориент-Ньюс» } \\
\text { и «Аль-Джа- } \\
\text { зира», сайт } \\
\text { «Джобар ньюс», } \\
\text { «Национальная } \\
\text { коалиция оп- } \\
\text { позиционных } \\
\text { и революцион- } \\
\text { ных сил Сирии», } \\
\text { «Сирийская об- } \\
\text { серватория по } \\
\text { правам челове- } \\
\text { ка» (Великобри- } \\
\text { тания), ИА «Рей- } \\
\text { тер». Указан газ } \\
\text { (!) «зарин» }\end{array}$ & \begin{tabular}{|c}
7 апреля ВМС США \\
нанесли ракетный \\
удар по авиабазе \\
аш-Шайрат крылаты- \\
ми ракетами \\
«Тмагавк». \\
Госсекретарь США \\
Рекс Тиллерсон в \\
эфире американско- \\
го телеканала СВS \\
выразил мнение, \\
что ответствен- \\
ность за поражение \\
населения лежит \\
на России. МИД \\
Франции считает, \\
что ОзХО предста- \\
вило доказательства \\
причастности армии \\
президента Сирии \\
Башара Асада к хи- \\
мической атаке в \\
провинции Идлиб. 20 \\
апреля министр обо- \\
роны США \\
Дж. Меттис заявил, \\
что САР все еще \\
хранит химическое \\
оружие
\end{tabular} & $\begin{array}{c}\text { Расследование } \\
\text { в дистанци- } \\
\text { онном режи- } \\
\text { ме. Миссия } \\
\text { ОзХО отдает } \\
\text { предпочтение } \\
\text { одним и тем } \\
\text { же западным } \\
\text { лабораториям. } \\
\text { Все пункты } \\
\text { доклада носят } \\
\text { вероятностный } \\
\text { характер, одна- } \\
\text { ко вывод дела- } \\
\text { ется конкрет- } \\
\text { ный - виноваты } \\
\text { вооруженные } \\
\text { силы Сирии. } \\
22 \text { ноября 2017 г. } \\
\text { В.А. Небензя, } \\
\text { постоянный } \\
\text { представитель } \\
\text { России в ООН, } \\
\text { назвал эксперт- } \\
\text { ную группу } \\
\text { оОН - ОЗХО } \\
\text { «мертвой» и } \\
\text { сказал, что } \\
\text { Москва готова } \\
\text { обсуждать } \\
\text { создание но- } \\
\text { вого механизма } \\
\text { расследования }\end{array}$ \\
\hline
\end{tabular}


Продолжение таблицы 1

\begin{tabular}{|c|c|c|c|c|c|}
\hline $\begin{array}{l}\text { Дата и } \\
\text { место }\end{array}$ & $\begin{array}{c}\text { Масштаб при- } \\
\text { менения (пред- } \\
\text { полагаемое ОВ) }\end{array}$ & $\begin{array}{l}\text { Контекст боевых } \\
\text { действий в Сирии }\end{array}$ & $\begin{array}{c}\text { Источники } \\
\text { сведений о } \\
\text { применении } \\
\text { химического } \\
\text { оружия }\end{array}$ & $\begin{array}{c}\text { Международная } \\
\text { реакция }\end{array}$ & $\begin{array}{c}\text { Позиция } \\
\text { ОзХО }\end{array}$ \\
\hline \begin{tabular}{|c|}
4 февраля \\
2018 г., при- \\
город г. Сара- \\
киб (провин- \\
ция Идлиб), \\
7 апреля \\
в Думе \\
(восточная \\
Гута) - серия \\
химических \\
провокаций \\
крайне при- \\
митивного \\
исполнения, \\
заключа- \\
ющихся в \\
подбрасыва- \\
нии в дома \\
мирных жи- \\
телей балло- \\
нов с хлором \\
и выкладыва- \\
нии в Үоитubе \\
однообраз- \\
ных видео с \\
использова- \\
нием детей \\
в качестве \\
жертв «хими- \\
ческого напа- \\
дения»
\end{tabular} & 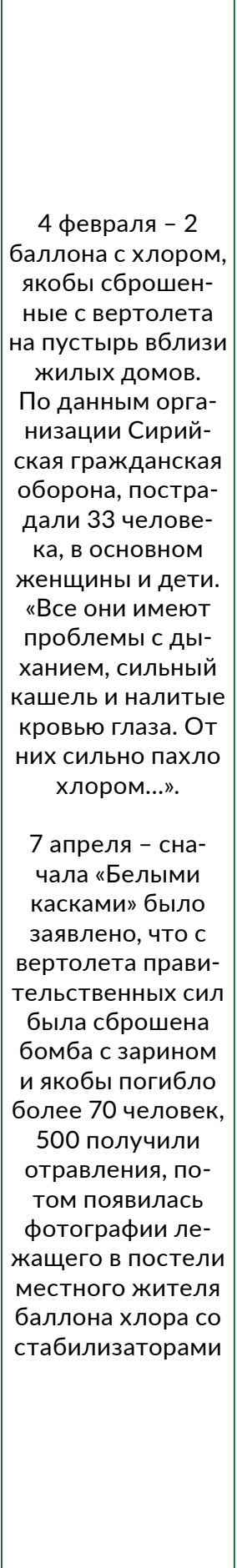 & $\begin{array}{c}\text { Наступление } \\
\text { сирийской армии на } \\
\text { г. Саракиб, форпоста } \\
\text { террористов } \\
\text { из группировки } \\
\text { «Джабхат ан-Нусра». } \\
\text { Широкомасштабное } \\
\text { наступление } \\
\text { правительственных } \\
\text { сил в провинциях } \\
\text { Идлиб, Алеппо и } \\
\text { Хама. На северо- } \\
\text { востоке провинции } \\
\text { Хама сирийская армия } \\
\text { во главе с элитной } \\
\text { бригадой «Щит } \\
\text { Каламуна» взяли } \\
\text { важный дорожный } \\
\text { узел - населенный } \\
\text { пункт Ходейде. } \\
\text { Окружение крупной } \\
\text { группировки } \\
\text { противника на } \\
\text { стыке границ } \\
\text { этих провинций. } \\
\text { Освобождение } \\
\text { стратегической } \\
\text { авиабазы Абу-Духур. } \\
\text { Нарушение боевиками } \\
\text { группировки } \\
\text { «Джейш аль- } \\
\text { Ислам» перемирия с } \\
\text { правительственными } \\
\text { войсками }\end{array}$ & $\begin{array}{c}\text { ВОЗ, «Белые } \\
\text { каски» } \\
\text { (Сирийская } \\
\text { гражданская } \\
\text { оборона), } \\
\text { экспертно- } \\
\text { журналистская } \\
\text { группа } \\
\text { «Bellingcat». } \\
\text { Cообщения по } \\
\text { мессенджеру } \\
\text { WhatsApp, NBC } \\
\text { News, блоги, } \\
\text { новостные } \\
\text { ленты }\end{array}$ & $\begin{array}{c}\text { б февраля } \\
\text { Госдепартамент } \\
\text { США выразил } \\
\text { беспокойство в связи } \\
\text { с сообщениями } \\
\text { о новом случае } \\
\text { применения хлора } \\
\text { властями Сирии в } \\
\text { Саракибе. Власти } \\
\text { США отмечали, что } \\
\text { это шестой такой } \\
\text { случай в Сирии } \\
\text { за месяц. В ночь } \\
\text { с 13 на 14 апреля } \\
\text { США, Франция и } \\
\text { Великобритания } \\
\text { нанесли ракетные } \\
\text { удары по Сирии. } \\
\text { Согласно данным } \\
\text { Министерства } \\
\text { обороны России, } \\
\text { удару подверглись } \\
\text { шесть военных } \\
\text { аэродромов (четыре } \\
\text { из которых не } \\
\text { пострадали), а также } \\
\text { объекты в районе } \\
\text { населенных пунктов } \\
\text { Барз и Джарамани, } \\
\text { относящиеся к } \\
\text { так называемой } \\
\text { «военной химической } \\
\text { программе» Дамаска, } \\
\text { которые давно не } \\
\text { используются, людей } \\
\text { и оборудования на } \\
\text { них не было. } \\
\text { Совет Безопасности } \\
\text { Оон 9 апреля } \\
\text { провел экстренное } \\
\text { заседание для } \\
\text { обсуждения } \\
\text { предполагаемой } \\
\text { химической } \\
\text { атаки в Думе. На } \\
\text { голосовании в } \\
\text { Совете Безопасности } \\
\text { оОН Россия, } \\
\text { применив право } \\
\text { вето, заблокировала } \\
\text { принятие проекта } \\
\text { резолюции, } \\
\text { преддлженной СшА }\end{array}$ & $\begin{array}{c}\text { Документ } \\
\text { ОЗХО } \\
\text { подготовлен } \\
\text { наспех, } \\
\text { составлен по } \\
\text { устоявшемуся } \\
\text { шаблону } \\
\text { предыдущих } \\
\text { докладов МУФ, } \\
\text { в частности, по } \\
\text { инциденту в } \\
\text { аль-Латамне в } \\
\text { марте } 2017 \text { г. } \\
\text { Одним из обоз- } \\
\text { наченных в док- } \\
\text { ладе способов } \\
\text { верификации } \\
\text { данных явля- } \\
\text { ется «анализ } \\
\text { открытых } \\
\text { источников». } \\
\text { Приводятся 32 } \\
\text { ссылки, в том } \\
\text { числе из «твит- } \\
\text { тера», «фейс- } \\
\text { бука», Үоитиые, } \\
\text { новостных } \\
\text { лент ВВС, СNN, } \\
\text { «Wаshіngton } \\
\text { Тітеs» и даже } \\
\text { пресс-релиза } \\
\text { Госдепарта- } \\
\text { мента США. } \\
\text { Напрашивается } \\
\text { вопрос, почему } \\
\text { МУФ не исполь- } \\
\text { зует материалы } \\
\text { с сайта МИД } \\
\text { России? }\end{array}$ \\
\hline
\end{tabular}


Сирийская «химическая война»

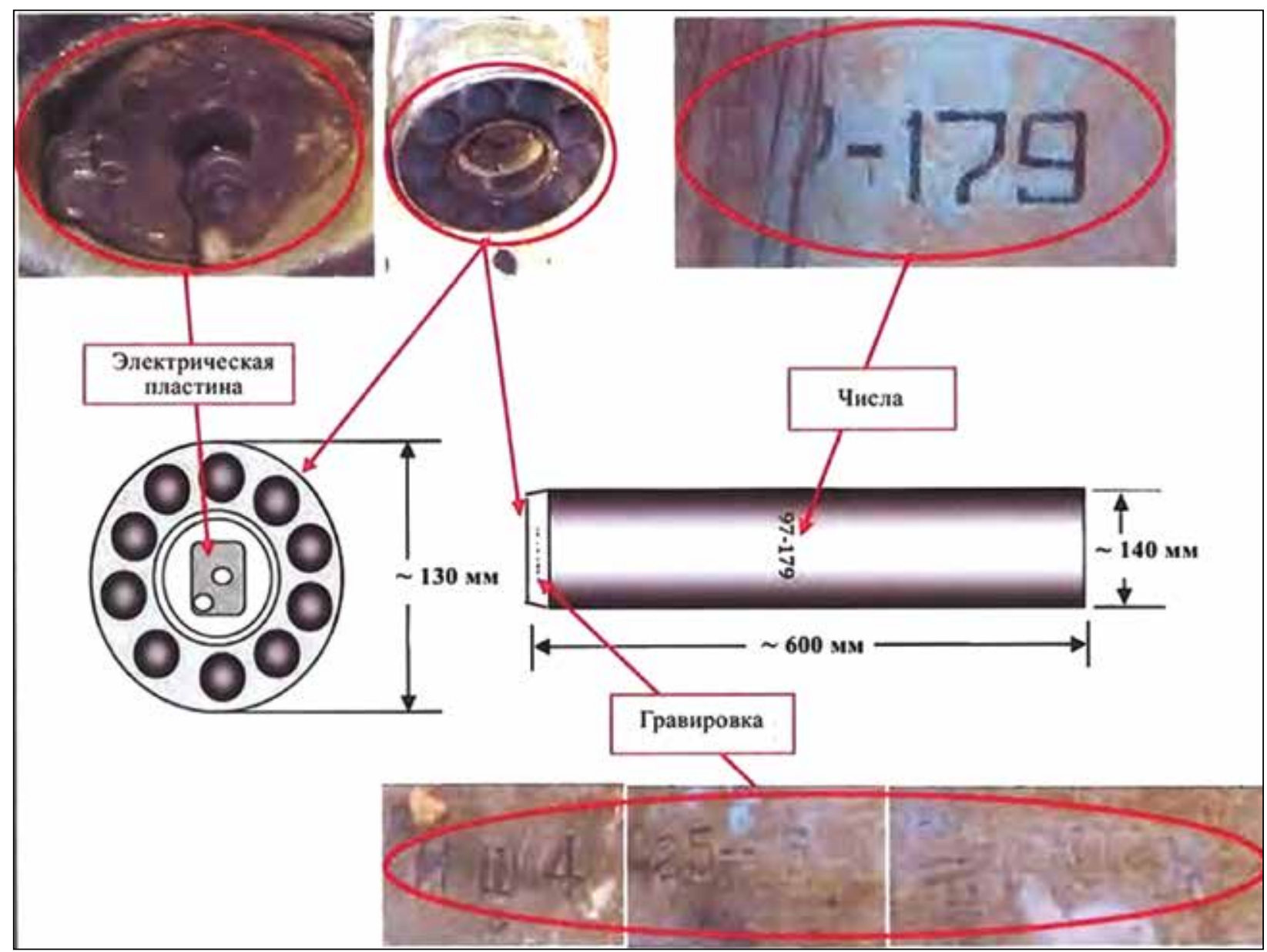

Рисунок 7 - Фрагменты 140-мм реактивного снаряда М-14 советского производства, подброшенные на место «преступления режима». Приведенная маркировка не может являться подтверждением того, что примененный снаряд был химическим, так как она относится только к ракетной части. Доказательства принадлежности найденной ракетной части к химическому боеприпасу отсутствуют

англоязычной версии доклада) ракетная часть, найденная в точке удара № 1 (Moadamiyah), принадлежит 140-мм реактивному снаряду (далее - РС) М-14 советского производства, снятого с вооружения (рисунок 7).

Указанные снаряды с осколочно-фугасной головной частью (далее - ГЧ) в значительных количествах поставлялись в страны Варшавского договора и «третьего мира». Отсутствие головной части (или ее фрагментов) на месте падения ракетной части и воронки от взрыва, а также отсутствие деформации корпуса свидетельствуют о том, что головная часть каким-то образом отделилась от ракетной части на траектории полета. Но штатная конструкция РС M-14 не предусматривает возможности отделения ГЧ на траектории полета. Проще говоря, у «свидетелей» и организаторов провокации ее не было во- обще, а ракетная часть была доставлена к месту падения другим способом ${ }^{14}$.

Снаряд, фрагменты которого были обнаружены в точке № 4 (с. 19-21, Zamalka/Ein Tarma), при внимательном рассмотрении оказался кустарно изготовленным. На это указывает конструктивное исполнение - отсутствие баллистического обтекателя, необоснованно массивная ГЧ, примитивный двигатель и качество изготовления. Снаряд имел кустарно изготовленный взрыватель, который не сработал (или его не было вообще). Вероятно, разрушение снаряда произошло в результате кинетического удара о преграду - стену и перекрытие нижнего этажа. Об этом свидетельствуют проломы и найденные фрагменты импровизированной ГЧ перед первой преградой, а также наличие фрагментов двигателя под пробитым перекрытием. При наличии взрывателя снаряд был бы разрушен при встрече

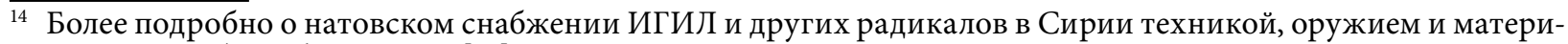
алами см. в работе Th. Meyssan [17].
} 
V.A. Kovtun, D.P. Kolesnikov, M.V. Supotnitskiy, N.I. Shilo

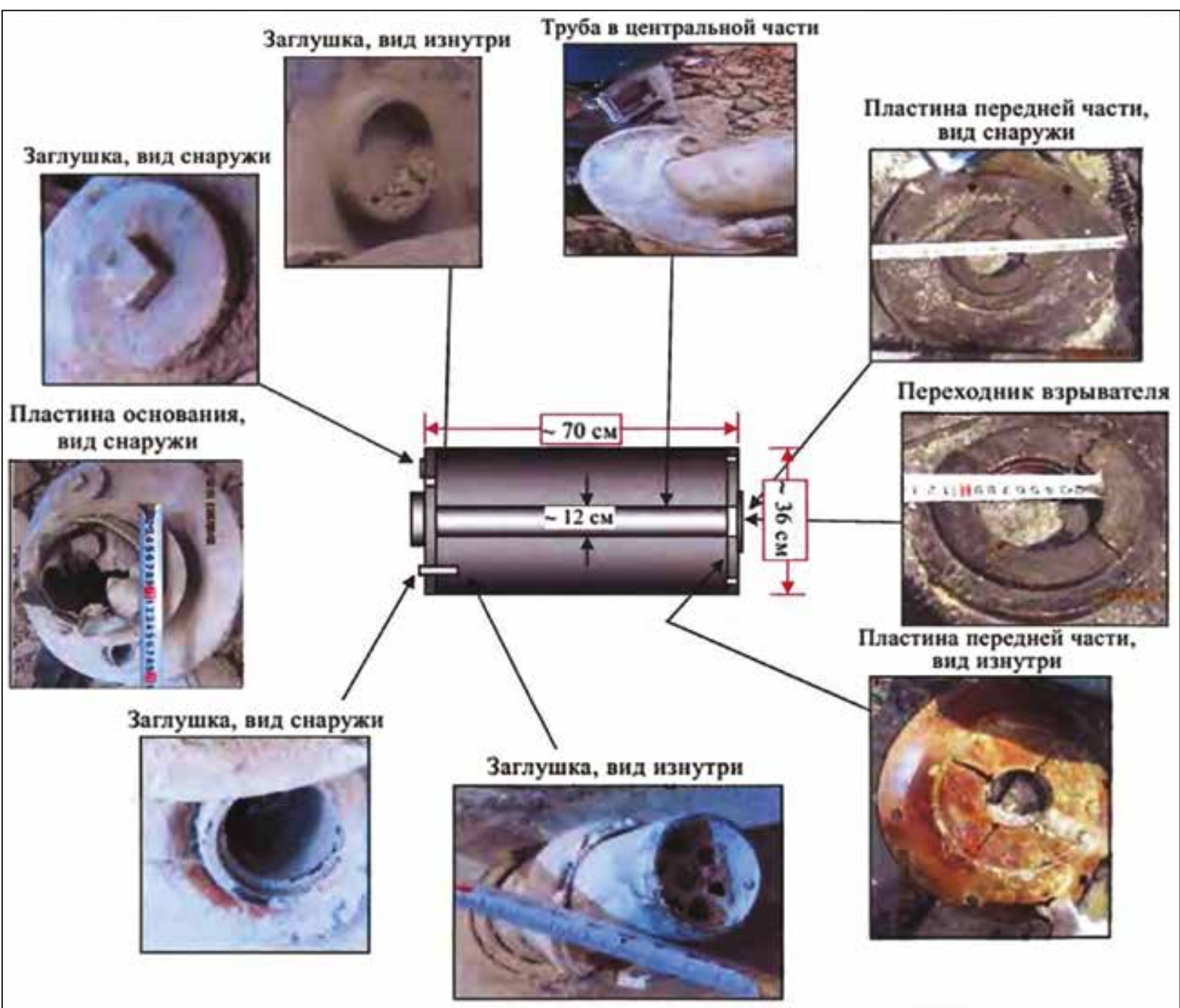

Рисунок 8-Кустарно изготовленный 360-мм химический снаряд.

Представляет собой емкость с чентрально расположенным зарядом взрывчатого вещества. Конструктивно - это примитивный аналог использовавшихся в годы Первой мировой войны американских химических мин МК II. Для наполнения жидким ОВ в корпусе снаряда имеется заливная горловина с заглушкой. Исходя из габаритов двигателя и конструкции снаряда, мы предполагаем, что дальность его полета не превышала 3 км, но заранее предсказать, куда такой снаряд nоnадет, невозможно

с первой преградой - стеной, так что пробить перекрытие он бы не смог (рисунок 8).

Применение одного или двух снарядов, особенно реактивных, имеющих значительное техническое рассеивание, не позволяет решить какую-либо тактическую задачу и, по сути, является бессмысленным при ведении общевойскового боя. Вместе с тем, одиночное применение реактивных снарядов характерно для иррегулярных вооруженных формирований еще со времен афганской войны.

Для разработчиков подобных дезинформаций характерна одна и та же «родовая травма», сопровождающая их все годы химической войны в Сирии. Их сочиняют гуманитарии, к химическому оружию отно- шения никогда не имевшие, а нанятые для ведения информационной войны. Они плохо понимают, о чем идет речь, поэтому имитируют химические нападения, как «газовую войну», т.е. буквально, по термину, принятому во время Первой мировой войны. Соответственно, химическое оружие у них - «газ». И действует оно следующим образом: после взрыва химического боеприпаса из него вырывается «газ», как из лопнувшего бытового баллона с пропаном, но ядовитый. И этот «газ» быстро уносится ветром, оставляя после себя сотни и тысячи трупов, при этом не заражая окружающую территорию, а трупы отравленных людей можно заносить в закрытые помещения без специальной обработки. 


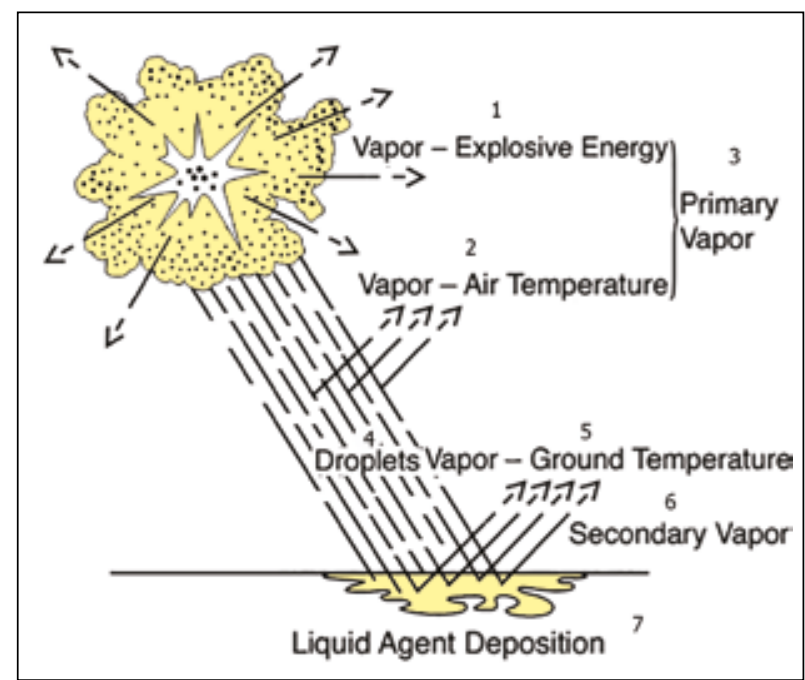

Рисунок 9- Распределение отравляющего вещества при взрыве химического боеприпаса. Количество пара, образующегося при взрыве бое nрипаса, зависит от энергии взрыва (1) и температуры воздуха (2), в результате формируется первичное облако пара ОВ (3). Не перешедшее в пар OB оседает в виде мельчайших капель (4) на почву (5) и постепенно испаряется, формируя вторичное облако пара ОВ (6), при этом сама территория, на которую выпали капли ОВ, представляет большую опасность для людей без средств защиты органов дыхания и кожи (7) [13]

В качестве «газа» обычно указывается зарин, так как про него им известно только то, что он «летучий» ${ }^{15}$. Но зарин - не газ, а жидкость. Температура кипения $\left(t_{\text {кип }}\right)$ зарина $=$ $151{ }^{\circ} \mathrm{C}$, т.е. он более летуч, чем $\mathrm{VX}^{\text {кил }}\left(t_{\text {кип }}=298^{\circ} \mathrm{C}\right)$ или табун $\left(t_{\text {кип }}=240^{\circ} \mathrm{C}\right)$, но он не испаряется, как этиловый эфир $\left(t_{\text {кип }}=35^{\circ} \mathrm{C}\right)$. Сразу из окружающей среды при такой температуре кипения исчезнуть невозможно [21-23]. При взрыве химического боеприпаса часть ОВ превращается в пар, часть оседает на землю, людей и окружающие их предметы в виде капель, сорбируется тканями, шерстью, древесиной, кирпичом, бетоном, впитывается в окрашенные поверхности и резинотехнические изделия, и только потом начинает испаряться [22] (рисунок 9) ${ }^{16}$.
Все фалышивки сирийской химической войны данное обстоятельство, сложное для понимания массовым зрителем, не учитывают. Достигается максимальная простота и доступность лжи. Хирургическая маска, болтающаяся под носом такого «спасателя» - это знак, подаваемый зрителям с телеэкрана, о существующей опасности - вдохнуть ядовитый «газ». Поэтому «спасатели» смело заносят в закрытые помещения людей, на коже и одежде которых в случае реального применения зарина должны осесть капли этого $\mathrm{OB}$, и начинают имитировать какие-то медицинские манипуляции. «Отравленный зарином», пуская пену изо рта, внимательно смотрит в камеру. Пострадавших среди актеров в хирургических масках не бывает ${ }^{17}$.

Примененный в Восточной Гуте 360-мм «химический снаряд", как считают авторы

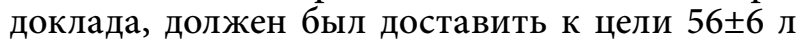
зарина. Так как он не взорвался, а разбился о стену здания, то большая часть зарина разбрызгалась и впиталась в почву и стены на месте его падения. Это означает, что на протяжении нескольких недель вокруг места падения снаряда должны происходить отравления людей зарином, и уж точно на следующий день обломки «боеприпаса», а тем более не проводя их дегазацию специальными дегазирующими составами, собирать крайне опасно.

На основании данных, характеризующих клинические особенности проявления интоксикации у пациентов (миоз, бронхоспазм, саливация, судорожный синдром, коматозное состояние), обследованных медицинскими экспертами Миссии, можно полагать о правомерности заключения авторов доклада о наличии признаков отравления веществами нервнопаралитического действия типа зарин различной степени тяжести. Фиксированная Миссией частота симптомов интоксикации у пораженных (преобладание коматозных состояний, нарушение со стороны дыхательной системы на фоне сравнительно низкого процента миоза и судорожной реакции) может быть обусловлена особенностями динамики развития интоксикации ФОВ на фоне проведенной антидотной терапии (атропинизация) - пациенты обследовались экспертами миссии на 5-7 сут. после

\footnotetext{
15 Летом зарин сохраняется на местности в жидком виде до 5 ч (без учета той его части, что впиталась в почву при взрыве боеприпаса), но его пары могут оказывать поражающее действие на этой местности и через 20 ч. Смертельные и очень опасные концентрации зарина могут возникать даже на расстоянии 15-25 км от места применения (более подробно см. в работе S. Franke [23]).

16 При десорбции зарина в воздухе накапливаются столь высокие концентрации его паров, что они могут оказаться смертельными. Это особенно касается закрытых помещений, в которых была сложена одежда, зараженная зарином (более подробно см. в работе S. Franke [23]).

17 Например, в этом видео показана вымышленная ситуация - «газ прошел»: URL: https://www.youtube.com/ watch?v=QRTiY9IC6QM (дата обращения: 20.07.2018 г.). При реальном взрывном диспергировании зарина его мельчайшие капельки остались бы на одежде людей и окружающих их предметах, сформировав вторичное облако паров этого ОВ. На «спасателях» средств защиты органов дыхания и кожи нет. Отсутствуют и признаки того, что производилась дегазация пораженных.
} 


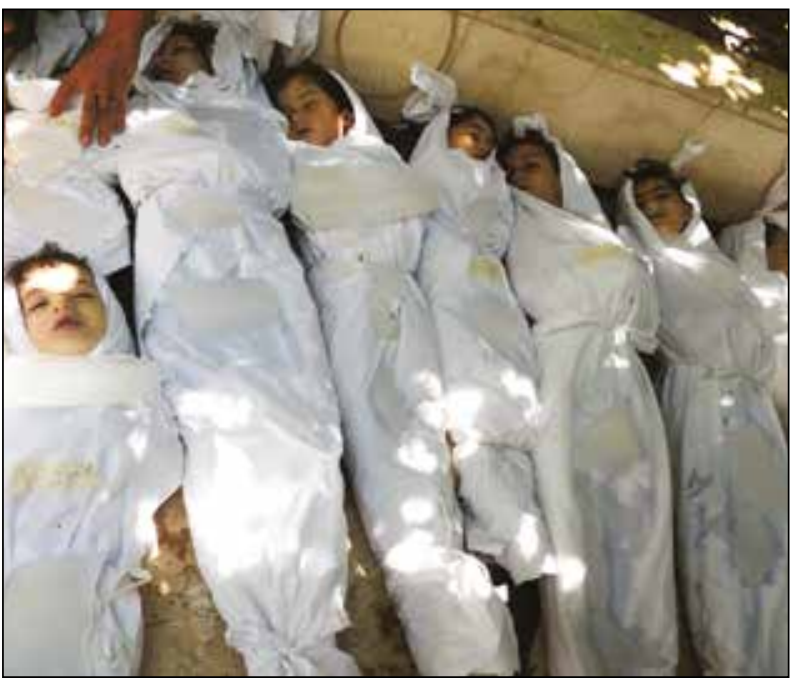

Рисунок 10-Дети из алавитских семей, убитыев пригороде Дамаска Восточная Гута ради имитачии «nреступлений Асада»'. Наблюдатели отмечают непропориионально большое число детей среди погибших - более одной трети. Не менее странным кажется тот факт, что зарином отравлены только дети и молодые мужчины, а женщин ОВ почему-то пощадило ${ }^{2}$

1 Фотография с ресурса URL: https://www. liveinternet.ru/users/841707/post290709628/ (дата обращения: 10.07.2018 г.).

2 На этом видео - URL: https:/www.youtube.com/ watch?v=indVgdPlP70 (дата обращения: 20.07.2018), загруженном в Youtube 21 августа 2013 г., т.е. сразу после химического нападения на Восточную Гуту, в основном показаны мертвые молодые мужчины и дети. Нет никаких признаков проведенной дегазации тел и одежды, на которых должен остаться зарин, если бы эти люди умерли в результате его применения. Сюжетно та же вымышленная ситуация «газ прошел», что и в других аналогичных видео. «Спасатели» либо в хирургических масках, либо вообще без них, и избегают показывать свои лица. Судя по освещению, видео снято в первой половине дня, вот только какого? По сути, на этом видео запечатлено массовое убийство сирийцев, но вне контекста «химической атаки Асада» оно никому не интересно.

поражения ФОВ, когда токсикогенная фаза отравления сменилась соматогенной, характеризующейся развитием типовых патологических процессов, сопровождающихся нарушением сознания, функционирования сердечнососудистой и дыхательной систем. Отсутствие данных биохимического исследования крови на степень выраженности угнетения холинэстеразы затрудняет объективизацию степени тяжести предполагаемого поражения ФОВ. Наличие у пострадавших раздражения слизистых глаз и верхних дыхательных путей (кашель, слезоточивость, раздражение слизистых глаз) не характерно для интоксикации ФОВ $[13,21]$. Сужение зрачков может быть получено закапыванием в глаза $1 \%$ раствора пилокарпина.

Детские трупы в сюжетах из Сирии, демонстрируемые от одной «химической атаки» к другой, навязываются руководителям государств, политикам различного уровня и обыкновенным обывателям с целью вызвать у них такой утробный ужас, чтобы они, ограничившись только эмоциональными переживаниями, не позволили себе обдумать произошедшее и засомневаться в его реальности, сведя все детали в цельную картину. Тогда они сами будут желать наказания «тирана», совершившего эти преступления, и априори поверят в любые другие его «преступления» (рисунок 10$)^{18}$.

Мертвые дети в сирийской химической войне стали продолжением более ранней лжи о пытках и убийствах детей, якобы показывающих античеловечность «режима Асада». Уже 18 марта 2011 г., во время нападения джихадистов на центр специальных служб в городе Дераа, а также начавшихся погромов и убийств горожан, телеканал «Аль-Джазира», прекрасно понимая, что происходит, выдавал эти события за протест жителей, вызванный тем, что полиция запытала до смерти детей, писавших на стенах домов лозунги против президента Асада. В мае 2011 г. финансируемая Госдепом США лондонская сирийская оппозиционная спутниковая телевизионная сеть Barada $\mathrm{TV}^{19}$ распространила кадры, на которых с тринадцатилетнего мальчика Хамзы Али аль-Хатиба живьем сдирают кожу. Его якобы пытали и кастрировали спецслужбы военно-воздушных сил Сирии. Этот сюжет был подан как доказательства пыток детей «режимом Асада». На этом фоне Германия, Франция, Португалия и Великобритания пытались протащить в Совете Безопасности $\mathrm{OOH}$ резолюцию, ставящую Сирию в то же положение, в каком находилась Ливия, но Россия и Китай нарушили этот план [17].

Таким образом, применение химического оружия сирийской армией в Восточной Гуте ${ }^{21}$ 6 августа 2013 г. не представляется доказанным фактом. Доказанным со многими оговорками является поражение людей зарином, но оно могло быть результатом применения зарина каким-то другим способом (как, например, в токийском метро 20 марта 1995 г.). В целом эти события представляют собой чудовищную по своей жестокости информационную провокацию против сирийского правительства со

\footnotetext{
18 Французские СМИ - В Сирии было совершено убийство детей для ложных фотографий химической атаки. URL: https://www.liveinternet.ru/users/841707/post290709628 / (дата обращения: 10.07.2018 г.).

19 Barada TV. URL: https://en.wikipedia.org/wiki/Barada_TV (дата обращения: 20.07.2018 г.).
} 
Сирийская «химическая война»

множеством погибших детей и взрослых, имеющую цель создать правовое обоснование нападению сил Запада на САР ${ }^{20}$.

Химический инцидент в населенных пунктах Тальменес (21 и 24 апреля), ат-Тамана, Кафр Зейта (апрель-август) в 2014 г., Северная Сирия, провинция Идлиб. Результаты расследования этих химических инцидентов обобщены в третьем докладе Миссии ОЗХО по установлению фактов применения химического оружия в Сирии (документ S/1230/2014 от 18 декабря 2014 г.) ${ }^{21}$. Расследование проводилось с нарушениями процедуры, определенной частью XI Приложения по контролю КХО. В соответствии с ней, основанием для направления инспекции ОЗХО в район предполагаемого применения химического оружия должен служить официальный запрос государстваучастника $\mathrm{KXO}^{22}$, предположительно подвергнувшегося химическому нападению. Однако основанием для данного расследования явились не запрос государства-участника, а сведения, полученные из СМИ. В задачи Миссии не входило выявление стороны, ответственной за применение ХО. Выдвижение представителей МУФ к месту происшествия состоялось 17 августа 2014 г. Результаты консультаций представителей МУФ с представителями САР, которые, как следует из доклада, проводились в течение всего периода, предшествующего выдвижению конвоя, в докладе не приводятся. Весь этот период, по данным, приведенным в докладе, случаи применения ХО на линии соприкосновения противоборствующих сторон продолжались с различной периодичностью.

В период с 22 августа по 5 сентября 2014 г. представителями МУФ был произведен опрос 37 пострадавших, медицинского персонала и свидетелей, доставленных к месту работы Миссии из 3 районов предполагаемого применения ХО. По их показаниям, в населенных пунктах Тальменес, ат-Тальмана и Кафр Зейта, расположенных на севере Сирии, неоднократно был применен хлор либо в чистом виде, либо в составе смеси. Каких-либо вещественных доказательств химических атак МУФ не собрала. В качестве их доказательств МУФ были приняты многочисленные видеозаписи (142 записи!), происхождение и достоверность которых ничем не подтверждены.

Исходя из обработки показаний свидетелей, подчас противоречивых, МУФ провоз-

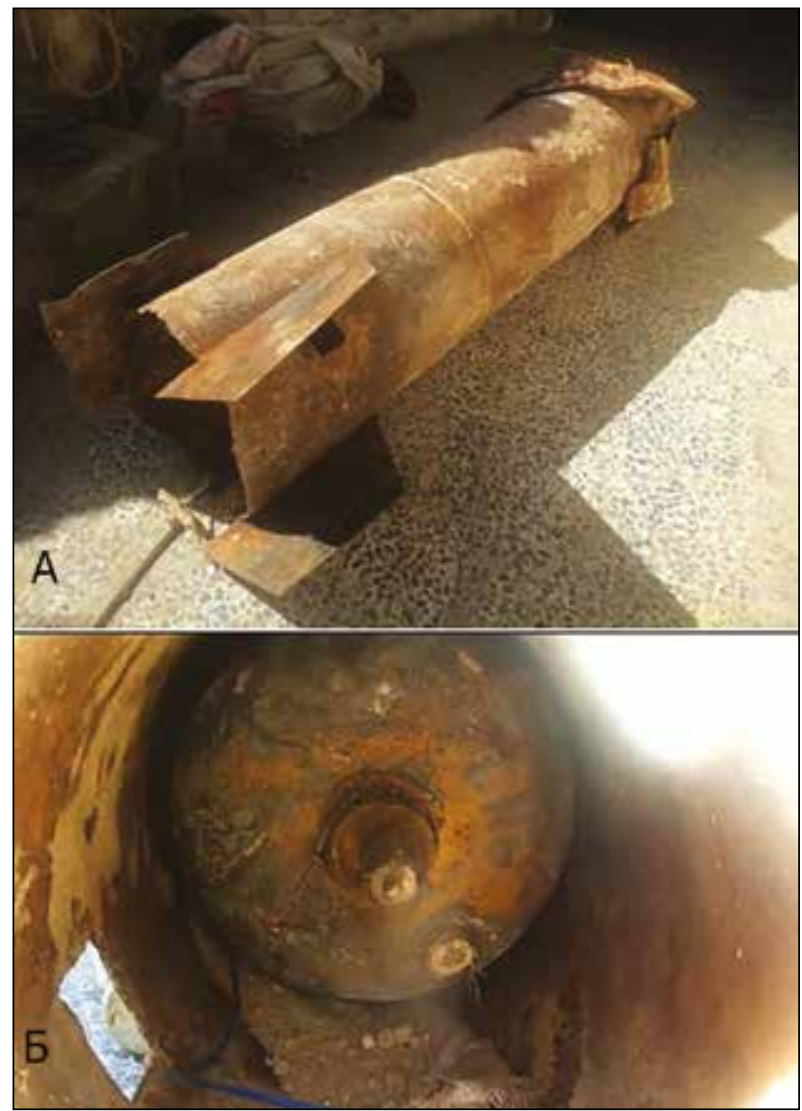

Рисунок 11 - Самодельный «авиационный боеприпас, снаряженный токсичным химикатом»'

(А. Внешний вид. Носовая часть «авиационного боеприпаса» Смята из-за удара о землю, либо ударами кувалды. Наблюдаются следы сквозной коррозии трубы. Б. Поперечное сечение «авиационного боеприпаса». Синий провод внутри бочки - детонирующий шнур примитивного взрывного устройства)

Third report of the OPCW Fact Finding mission in Syria. S/1230/2014 (18 декабря 2014 г.). URL: https://www. opcw.org/fileadmin/OPCW/Fact_Finding_Mission/s1230-2014_e_.pdf (дата обращения: 20.07.2018 г.).

гласила, что в период апрель-август 2014 г. в районах населенных пунктов Тальменес, ат-Тальмана и Кафр Зейта, расположенных на площади радиусом около 15 км, сброшены баллоны с хлором заводского производства, помещенные в старые проржавевшие железные трубы с приваренными стабилизаторами. Большая часть из них не взорвалась и была использована для съемки видео о «преступлениях режима Асада». Но эти самоделки МУФ

\footnotetext{
20 Российскому руководству провокационный характер акции был понятен сразу. На Youtube 31 августа 2013 г. выложено заявление президента В.В. Путина, в котором данные события называются провокацией, имеющей цель втянуть в конфликт другие страны. URL: https://www.youtube.com/watch?v=UB8VuQn9MOg (дата обращения: 20.07.2018 г.).

21 Third report of the OPCW Fact Finding Mission in Syria. S/1230/2014 (18 декабря 2014 г.). URL: https://www. opcw.org/fileadmin/OPCW/Fact_Finding_Mission/s-1230-2014_e_.pdf (дата обращения: 20.07.2018 г.).

22 САР присоединилась к КХО 14 октября 2013 г.
} 


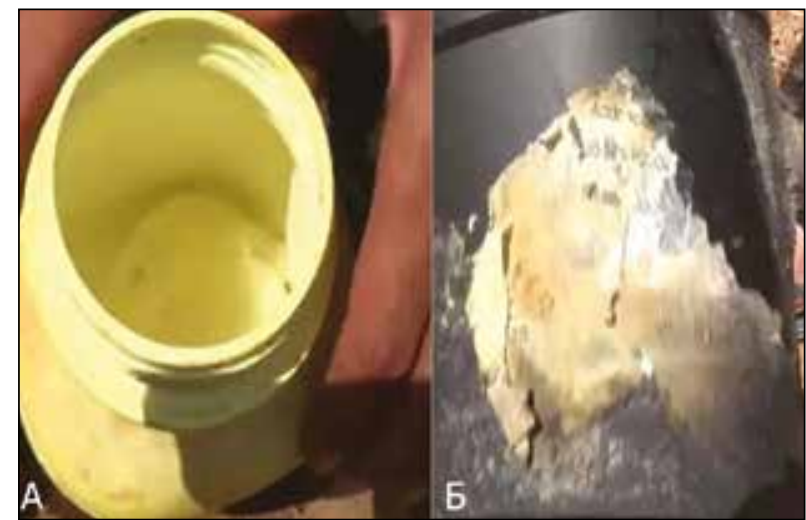

Рисунок 12 - Компоненты «бинарного оружия» (А. Желтый порошок в желтой банке. Б. Черная емкость с серной кислотой. При соединении содержимого желтой и черной емкостей якобы должен выделятьсяхлор. Конструкция такого «бинарного оружия» сильно отличается от приведенной на рисунке 3)

Third report of theOPCW Fact Finding Mission in Syria. S/1230/2014 (18 декабря 2014 г.). URL: https://www.opcw.org/fileadmin/OPCW/Fact_Finding_Mission/s-12302014 e_.pdf (дата обращения: 20.07.2018 г.).

солидно назвала «авиационными боеприпасами, снаряженными токсичным химикатом, предположительно хлором» (рисунок 11).

По оценкам МУФ, количество пострадавших в результате применений ХО в не менее, чем в 21 инциденте, составило несколько сот человек, у которых последствия воздействия токсичных химикатов к моменту работы МУФ полностью исчезли. По словам «свидетелей», число жертв составило 13 человек. В основном это люди, оказавшиеся в эпицентре случайного взрыва такого «авиационного боеприпаса».

Bce случаи применения химического оружия описывались «свидетелями» как однотипные и представляли собой якобы сброс с высоко летящего вертолета бочкообразной бомбы, при срабатывании которой вследствие удара о поверхность происходило вскрытие баллонов с хлором. «Авиационный боеприпас» содержал маломощное взрывное устройство с ненадежным детонатором, мощность которого достаточна для «мягкого» вскрытия оболочки и горловины баллона с высвобождением хлора (п. 5.32 отчета). При этом оставались некие «материальные свидетельства» применения химического оружия Асадом (фрагменты баллона с хлором и взрывного устройства, смятая бочка со стабилизаторами).

Конструкция такого рода «боеприпасов» не была стандартизирована различалась от изделия к изделию. В некоторых «авиационных боеприпасах», кроме баллона с хлором, в оболочку из ржавой железной трубы помещались подручные емкости с химикатами, например, с серной кислотой или другие, не имеющие маркировки. Такие «боеприпасы» МУФ назвала «бинарным оружием» (рисунок 12).

Большое количество видеоматериалов, приложенных к докладу в качестве «доказательств», говорит о том, что интенсивная видеосъемка была заблаговременно кем-то организована. Отдельные видеоролики представляют учебные фильмы о сборке и применении «бочковых бомб», сопровождаемые дикторским текстом, например, видео 105, 111 и 142.

Сразу же после опубликования второго доклада Миссии (10 сентября 2014 г.), в западных СМИ появилось множество публикаций, в которых со ссылками на высказывания официальных лиц утверждалось, что МУФ возложила ответственность за неоднократное применение химического оружия на севере Сирии на регулярную армию, подчиненную правительству $\mathrm{CAP}^{23}$, хотя в докладе МУФ таких утверждений не содержалось.

Основным аргументом СМИ и цитируемых официальных лиц служит то обстоятельство, что, в отличие от армии САР, силы оппозиции якобы не снабжены вертолетами. Вместе с тем, анализ периодичности инцидентов и их географической привязки свидетельствует о том, что сброс бочковых бомб мог быть осуществлен с помощью единственного вертолета, переоборудованного для этой цели. Учитывая уровень материально-технического снабжения оппозиции спонсорами террора, аренда (или захват) вертолета или покупка кувалды вполне доступны как для оппозиции, так и для любой другой группировки, заинтересованной в дискредитации сирийского правительства в отношении нарушения КХO.

Особо отметим, что применение точечных ударов с высвобождением в каждом нескольких десятков килограммов хлора не могло быть продиктовано какими-либо военными целями. Хлор в Первую мировую войну применялся в 1915-1916 гг. не килограммами, а сотнями тонн в форме массированных, внезапных и тща-

\footnotetext{
23 В частности, такого рода публикации доступны на сайтах URL: http://www.viewstimes.com/chlorinegas-used-systematically-and-repeatedly-in-syria-4249 (дата обращения: 20.07.2018г.). URL: http://edition.cnn. com/2014/09/10/world/meast/syria-chemical-weapons/index.html (дата обращения: 20.07.2018 г.). URL: http:// www.nytimes.com/2014/09/11/world/middleeast/watchdog-agency-concludes-chlorine-used-as-weapon-in-syria. html?ref=world\&_r=0 (дата обращения: 20.07.2018 г.). URL: http://www.huffingtonpost.com/2014/09/10/syriachemical-weapons_n_5800198.html (дата обращения: 20.07.2018 г.). URL: http://news.yahoo.com/watchdog-confirmssystematic-chlorine-attacks-syria-153413607.htm (дата обращения: 20.07.2018 г.).
} 
тельно подготовленных газопусков, осуществлявшихся инженерными подразделениями. Самостоятельно хлор из баллона выходит медленно, так как при переходе жидкого хлора $\left(t_{\text {кип }}=\right.$ минус $\left.34{ }^{\circ} \mathrm{C}\right)$ в газообразное состояние поглощается много тепла из окружающей среды и баллон замерзает. Поэтому газопуски проводили путем объединения тысяч баллонов в газовые батареи [13, 24-26].

Существовали боевые нормы выпуска хлора, обусловленные решаемыми тактическими задачами. Например, боевая норма 1200 кг/км/мин означала расход хлора в 1200 кг на фронте выпуска в один километр в течение одной минуты. Для снаряжения авиабомб хлор непригоден из-за малой токсичности и высокой летучести $[27,28]$. На русском фронте в 1916 г. непродолжительное время применялись бомбы, заполненные жидким хлором, но их боевая эффективность равнялась нулю и от них отказались [29]. Британцы в 1915-1917 гг. применяли хлор для снаряжения мин, но в смеси с более токсичным и менее летучим ОВ фосгеном (в соотношении 1/1). Смесь называлась «Белая звезда». Использование «Белой звезды» на фронте было вынужденным из-за нехватки OB, пригодных для артхимстрельбы [3].

Таким образом, всефакты свидетельствуют о том, что применение хлора с помощью невзрывающихся «авиационных боеприпасов» осуществлялось террористическими группировками с провокационными целями.

Химические инциденты в деревнях Кменас и Сармин (провинция Идлиб), 16 марта-20 мая 2015 г. Результаты расследования этих инцидентов приведены в отчете S/1319/2015 от 29 октября 2015 г. $^{24}$. В соответствии с п. 16 Части ХI Приложения по проверке к КХО, при расследовании в случаях применения химического оружия инспекционная группа должна отбирать пробы самостоятельно или с помощью государства-участника под непосредственным наблюдением инспекторов. Это требование не было выполнено в связи с отказом группы посетить районы инцидентов из соображений безопасности, о чем указывается в п. 2.10 доклада.

Пробы из объектов окружающей среды в количестве 24 образцов, якобы отобранные очевидцами в одном из семи населенных пунктов (Сармин), как и другие «доказательства», были переданы МУФ неправительственной организацией, так называемым «Сирийским центром документирования химических нарушений» (CVDCS), явно настроенным враждебно по отношению к пра-

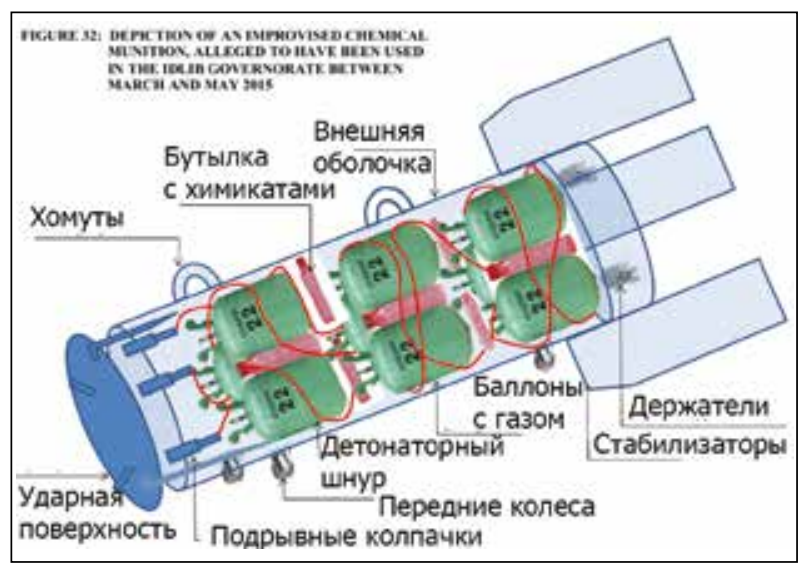

Рисунок 13 - Схема самодельного «авиационного бинарного боеприпаса», придуманного составителями доклада. Прямая цитата: «В связи с окислительными свойствами перманганата калия, он может использоваться для окисления хлорсодержащего соединения, приводящего к выделению $\mathrm{Cl}_{2}$, в результате которого появляется запах, похожий назапах отбеливателя, описываемый опрошенными» (n.5.17 доклада)

вительству САР. В 2014 г. МУФ отказывалась принимать пробы от «очевидцев», мотивируя это нарушением принципа «Chain of custody», заключающегося в соблюдении строгой последовательности действий для обеспечения сохранности доказательств. Однако это требование почему-то было проигнорировано при данном расследовании. Нарушение требований КХО к отбору проб признается и в докладе МУФ. Таким образом, пробы, полученные МУФ и в дальнейшем подвергнутые анализу в назначенных О3ХО лабораториях, не могут быть признаны легитимными.

Результаты анализа проб, приведенные в п. 3.72, не позволяют сделать сколько-нибудь однозначных выводов. По сути, выявлено лишь присутствие в отдельных пробах повышенных концентраций калия, марганца и хлоридов. Да и сами авторы доклада признают, что результаты исследования проб в ходе данного расследования являются крайне неубедительными (п. 5.16). Тем не менее они сделали глубокомысленное предположение о «бинарной системе применения хлора с использованием в качестве компонентов перманганата калия с одной стороны и некоего хлорсодержащего соединения, с другой стороны». Была даже представлена гипотетическая схема самодельного «авиационного бинарного боеприпаса» (п. 3.179 доклада) с размещенными в нем сосудами с указанными компонентами (рисунок 13).

\footnotetext{
${ }^{24}$ Report of the OPCW Fact Finding Mission in Syria regarding alleged incidents in the Idlib governorate of the Syrian Arab Republic between 16 March and 20 May 2015.
} 
Данная схема представляет собой пародию на бинарный боеприпас (см. рисунок 3). Эффективность такого боеприпаса в отношении формирования облака хлора приближается к нулю. Поэтому использование боеприпаса такого рода в населенных пунктах представляет собой имитацию применения химического оружия.

Не составляет труда оценить ожидаемые потери при далеко не оптимальном совокупном использовании нескольких «бомб» во всех рассматриваемых инцидентах и прийти к выводу, что фактические потери не идут ни в какое сравнение с потерями, которые могли бы быть достигнуты применением обычного оружия. Следовательно, замысел на применение хлора (или соединения с запахом хлора) мог быть обусловлен лишь террористическими и провокационными целями. Тем не менее, эти инциденты нашли свое отражение в докладе Совету Безопасности $\mathrm{OOH}$ и вызвали серьезный международный резонанс (см. таблицу 1).

Химические инциденты 24, 25 и 30 марта 2017 г., деревня аль-Латамна в уезде Махарда, провинция Хама. По всем трем инцидентам МУФ, ссылаясь на ограничения, связанные с безопасностью, провела расследование дистанционно, нарушив базовый принцип «Chain of custody». Вещественные доказательства собирались и направлялись экспертам МУФ представителями организации «Белые каски», не раз уличенной в создании фейковых новостей ${ }^{25}$. Имеются факты, которые свидетельствуют, что спасатели из этой якобы гуманитарной организации на самом деле тесно связаны с террористической группировкой «Джабхат ан-Нусра ${ }^{26}$. Поэтому говорить о том, что вещественные доказательства, использованные МУФ, имеют несфабрикованный характер, не представляется возможным.

В отчете S/1636/2018 от 13 июня 2018 г. рассмотрены два инцидента, в одном из которых (24.03.2017 г.) подозревается применение зарина, во втором (25.03.2017 г.) - применение хлора.

Пробы передавались МУФ неправительственными организациями. Утверждалось, что они якобы отобраны в местах инцидентов. Пробы были отправлены в лабораторию ОЗХО и затем, после их разделения - в две назначенные лаборатории для анализа. По первому инциденту анализу были подвергнуты 12 проб из объектов окружающей среды, по второму 25 проб.

По инциденту 24.03.2017 г. установлено следующее. В большинстве проб обнаружен набор компонентов, характерных для рецептуры зарина, полученной по бинарной технологии. В отчете приводятся сравнительные данные по составу компонентов проб, отобранных в аль-Латамне 24.03.2017 г. с результатами анализа проб, полученными ранее при расследовании инцидентов в Хан-Шейхуне 04.04.2017 г. и в аль-Латамне 30.03.2017 г. Данное обстоятельство позволяет предположить возможность использования «заинтересованными лицами» некой «стандартной» смеси для внесения в пробы с целью их фальсификации.

По инциденту 25.03.2017 г. установлено следующее. При проведении органического анализа в пробах обнаружен большой набор хлорорганических соединений. Их присутствие в пробах доклад увязывает с возможным применением хлора. На самом деле большинство из таких соединений (например, трихлорфенол) относятся к антисептикам и сопутствующим продуктам. Поэтому присутствие их в пробах, отобранных в помещении больницы, вполне объяснимо. Наряду с хлорорганическими соединениями, в ряде проб обнаружен диизопропил метилфосфонат (DIMP) - технологическая примесь при производстве зарина. Авторы доклада не связывают его с применением зарина в данном инциденте, а объясняют его наличие тем, что в данном помещении проводилась днем раньше дегазация водой (!) ${ }^{27}$ пострадавших в инциденте 24.03.2017 г. В таком случае возникает вопрос: куда делись все другие компоненты рецептуры зарина, обнаруженные в пробах, относящихся к тому инциденту? Принимая во внимание, что DIMP является наиболее летучим из всех примесей к зарину и малорастворим в воде, эти данные

\footnotetext{
25 Ахмад Салах. «Белые каски» Сирии - вымысел и реальность. Какую роль они играют в информационной войне // Свободная Пресса. 2016. 17 октября. URL: https://svpressa.ru/blogs/article/158679 / (дата обращения: 15.07.2018 г.).

26 Били В. (Vanessa Beeley). «Белые-каски»: марионетки-провокаторы западных спецслужб. URL: http://www. tabula.su/vostok/whitehelm.html (дата обращения: 15.07.2018 г.). «Джебхат ан-Нусра» (Фронт ан-Нусра) - отделение международной исламистской террористической организации «Аль-Каида» на территории Сирии и Ливана. Организация признана террористической по решению Верховного суда РФ от 29.12.2014 г.

27 Для дегазации местности, зараженной зарином, используют растворы щелочей и гипохлоритов или суспензии хлорной извести. Транспорт, боевую технику, помещения дегазируют растворами щелочей или гипохлоритов. Растворы аммиака, соды, фенолята, а также извести применяют для дегазации материалов, легко корродирующих при действии щелочей. Для дегазации кожи человека и предметов личного снаряжения применяют хелаты двухвалентной меди, гидроксамовые кислоты, разбавленные растворы перекиси водорода и слабощелочные растворы (более подробно см. в работе S. Franke [23]).
} 
Сирийская «химическая война»

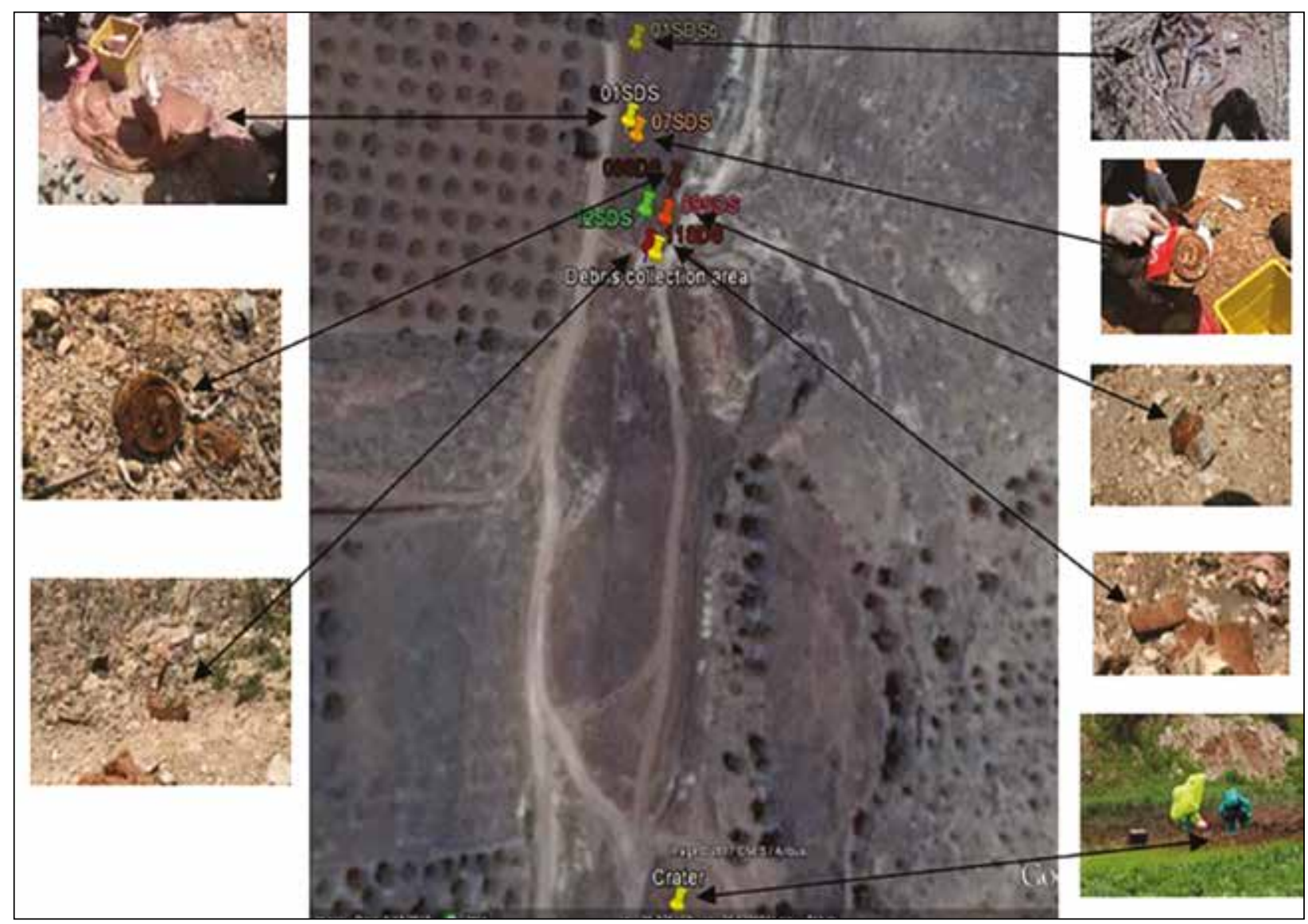

Рисунок 14-Сбор «Белыми касками» «вещественных доказательств» применения зарина «режимом Асада». На пустыре за деревней аль-Латамне из земли какие-то люди выкапывают ржавые металлические фрагменты, лежащие, судя по ржавчине, тут не один год. Люди в защите на снимке справа внизу явно сняты в другой климатической зоне

\footnotetext{
Report of the OPCW Fact Finding mission in Syria regarding an alleged incident in Ltamenah, the Syrian Arab Republic, 30 March 2017. S/1548/2017, P. 14.
}

не поддаются объяснению. Кроме того, аналогичная комбинация хлорорганических и фосфорорганических соединений наблюдалась, согласно прежнему докладу МУФ, и в других пробах, отобранных в месте предполагаемого применения хлора. В том случае этот факт не связывался с проведением дегазации пострадавших. Все это наводит на мысль об использовании некого «букета» списочных токсических химикатов для искусственного внесения в пробы с целью их фальсификации.

Наряду с анализом органических соединений, одна из назначенных лабораторий представила данные неорганического анализа проб на содержание основных анионов и катионов. Повышенное содержание анионов хлора ассоциируется в докладе с применением хлора. Вместе с тем, обращает на себя внимание весьма строгая корреляция содержания анионов хлора и катионов кальция в соотношении 2:1, характерная практически для всех проб. Такое соотношение следует объяснить нали- чием в пробах гипохлорита кальция (хлорной извести) - вещества, широко применяемого для дезинфекции больничных помещений, где и были отобраны пробы. Использовать данный результат анализа как подтверждающий применение хлора не корректно. С учетом приведенных данных, исходя из результатов анализа проб, сделанные в докладе выводы о «весьма вероятном» применении в аль-Латамне зарина 24.03.2017 г. и хлора 25.03.2017 г. представляются весьма сомнительными.

30 марта 2017 г. химическому нападению с применением зарина подверглась более чем странная для химического оружия цель - группа фермеров на пустыре. В отчете S/1548/2017 от 02 ноября 2017 г. указано, что расследование велось «на основании только интервью, которые, где было возможно, подтверждены разными интервьюируемыми лицами». МУФ, ссылаясь на ограничения, связанные с безопасностью, как обычно отказалась посетить место инцидента и провела расследование дистанционно 
(п. 4.5 доклада), находясь в «соседней стране» (п. 1.2 доклада). При расследовании инцидента, в соответствии с п.п. 1.2, 4.7, 4.10, 5.30 доклада, вещественные доказательства собирались и направлялись экспертам МУФ представителями не раз уличенной в создании фейковых новостей организации «Белые каски» (рисунок 14).

Таким образом, говорить о том, что вещественные доказательства, использованные МУФ, имеют «чистый» и несфабрикованный характер, не представляется возможным. Такой же вывод можно сделать и в отношении биомедицинских проб. Согласно п. 5.36 доклада, в присутствии представителей МУФ у двух лиц, предоставленных или рекомендованных «Белыми касками», 29.07.2017 г. были отобраны четыре биомедицинские пробы, анализ которых двумя назначенными лабораториями не дал никаких результатов. При этом в докладе данное обстоятельство трактуется все же в пользу наличия факта применения ФОВ.

Нет никаких подтверждений и того, что «свидетели» действительно находились в аль-Латамне. В п. 5.13 доклада указано, что «ни один из опрошенных свидетелей не видел, чтобы самолеты сбрасывали боеприпасы в их районе». В докладе и выводах присутствуют такие слова, как «возможно», «более чем вероятно», «можно предположить» и т.д. Лексика, совершенно недопустимая для доклада, претендующего на статус солидного и тщательно выверенного документа. Отсутствуют данные и о том, какие задачи были поставлены назначенным лабораториям О3ХО.

Результаты анализа экологических проб, представленные двумя назначенными лабораториями, вызывают вопросы, поскольку в отчете МУФ не приводятся конкретные результаты анализа каждой из двух лабораторий, а приведены только обобщенные данные (таблица 3 доклада). Первичная оценка этих данных свидетельствует о том, что в сравнении с результатами анализа проб, относящихся к инциденту в Хан-Шейхуне (см. S/1510/2017 от 29.06.2017 г.), пробы, якобы относящиеся к инциденту в аль-Латамне, содержат гораздо более широкий и отличающийся набор примесей, что косвенно может свидетельствовать о том, что для имитации данного инцидента использовался зарин, изготовленный по иной технологии.

Характеристики воронки, образовавшейся в результате взрыва, в соответствии с п. 5.28 доклада: «Место взрыва, имеющее отношение к третьему взрыву, по оценкам свидетелей, было 1-1,5 м в диаметре и глубиной приблизительно 25 см», не соответствуют воронке от взрыва авиационного химического боеприпаса и похожи на воронку от так называемой «химической авиационной бомбы» в Хан-Шейхуне (подробный разбор данного вопроса, проведенный при анализе инцидента в Хан-Шейхуне, приведен ниже). Видимо, в аль-Латамне «Белыми касками» была проведена генеральная репетиция Хан-Шейхуна, а затем, по прибытии специалистов МУФ, данный инцидент также был использован в их грязной игре.

Вывод, сделанный МУФ в п. 6.7: «Хотя фрагменты боеприпасов не могли быть категорически отнесены к предполагаемому инциденту 30 марта 2017 г., однако их присутствие на месте, их заражение зарином и химикатами, имеющими отношение к зарину, а также характерные признаки, соответствующие химическим боеприпасам, указывают на вероятность того, что они имели отношение к доставке химического оружия», туманен и не подкреплен доказательной базой. Непонятна сама цель, с которой якобы сброшена одиночная «химическая бомба» на пустырь, если только не для фотосессии. Химическое оружие - это оружие массового поражения. Основные принципы его применения - массовое воздействие на противника и достижение максимально возможной концентрации паров $\mathrm{OB}$ в районе цели, но они не соблюдены ни в данном случае, ни в других. Таким образом, и этот доклад содержит нестыковки и подтасовки фактов, что ставит под сомнение корректность выводов, сделанных на основе содержащихся в нем фактических данных и результатов анализов.

Химический инцидент 4 апреля 2017 г., город Хан-Шейхун (провинция Идлиб). Эта якобы совершенная "режимом Асада» химическая атака на жителей города Хан-Шейхун послужила для США предлогом для нанесения 7 апреля 2017 г. мощного ракетного удара по авиабазе аш-Шайрат крылатыми ракетами «Томагавк». Сирийские власти сообщили о гибели 7 военнослужащих и 9 мирных жителей. Ниже приведена хронология этого преступления ${ }^{28}$.

\section{3 апреля:}

американские эсминцы «Росс» и «Портер» вышли из пунктов постоянного базирования и с

\footnotetext{
28 Использовались материалы с интернет-ресурсов:

Химический фейк в Идлибе URL: https://colonelcassad.livejournal.com/3356267.html (дата обращения: 15.07.2018 г.) Гашков И. Кто применил химоружие в Хан-Шейхуне: Гаага возобновляет расследование // РИА-новости. 2017. 19 апреля. URL: https://ria.ru/world/20170419/1492515769.html (дата обращения: 15.07.2018 г.)

Рачева Е. Химическая атака в городе Хан-Шейхун сирийской провинции Идлиб произошла 4 апреля. Погибло не менее 89 человек, пострадали больше 557 // Политика. 2017. № 38. 12 апреля. URL: https://www.novayagazeta. ru/articles/2017/04/12/72116-samolet-videli-ili-slyshali-pochti-vse (дата обращения: 15.07.2018 г.).
} 
максимальной скоростью через 72 ч прибыли в заданный район пуска крылатых ракет в восточной части Средиземного моря ${ }^{29}$.

4 апреля:

6.30 - «авиаудар» по городу Хан-Шейхун, после которого появился странный запах и первые пораженные (со слов Мунзера Халила - главы здравоохранения Идлиба);

8.00 - связанные с радикальными группировками фриланс-журналисты Муазз аш-Шами и Абдулла аль-Гани, находящиеся в Идлибе, предоставили медиа-ресурсам сирийской оппозиции и телеканалам «Ориент-Ньюс» и «Аль-Джазира» подготовленные с участием «Белых касок» видеосюжеты о «последствиях» того, что они назвали «авиационным ударом с использованием химического оружия» по окраине г. Хан-Шейхун. Муазз ашШами в своем сюжете использовал словосочетание «газ зарин»;

9.50 - оппозиционный сайт «Джобар ньюс» обвинил правительственные войска в применении зарина и сообщил о 40 пострадавших;

10.00 - Национальная коалиция оппозиционных и революционных сил Сирии (НКОРС) выступила с заявлением о том, что более 54 человек погибло и не менее 80 пострадало вследствие «химической атаки» со стороны правительственных сил Сирии. Большинство пострадавших было эвакуировано в Турцию, в медучреждения г. Газиантеп;

10.41 - «Сирийская обсерватория по правам человека» (Великобритания) распространила на своем сайте информацию о применении ВКС РФ химического оружия в провинции Идлиб (Сирия), сообщив о гибели уже 58 человек;

11.08 - ИА «Рейтер» разместило аналогичный информационный материал, ссылаясь на данные «Сирийской обсерватории по правам человека». Информация о применении сирийской армией в районе Хан-Шейхуна «химического оружия» и «газа оружия» начала стремительно распространяться в зарубежных СМИ и социальных сетях;

12.30 - новостное агентство «Аль-Масдар Ньюс» (Ливан) распространило сообщение, что сирийская армия в г. Хан-Шейхун провинции Идлиб уничтожила фабрику по производству химического оружия боевиков;

15.00 - Париж выступил с инициативой созвать экстренное заседание Совбеза ООН по данному вопросу. Далее последовало заявление спецпосланника ООН по Сирии Стаффана де Мистуры: «То, что произошло сегодня утром, мы обсуждали это с Ф. Могерини, ужасно. Мы требуем, и $\mathrm{OOH}$ потребует, и я уверен, что будет заседание Совбеза $\mathrm{OOH}$ по этому вопросу, для определения ответ-

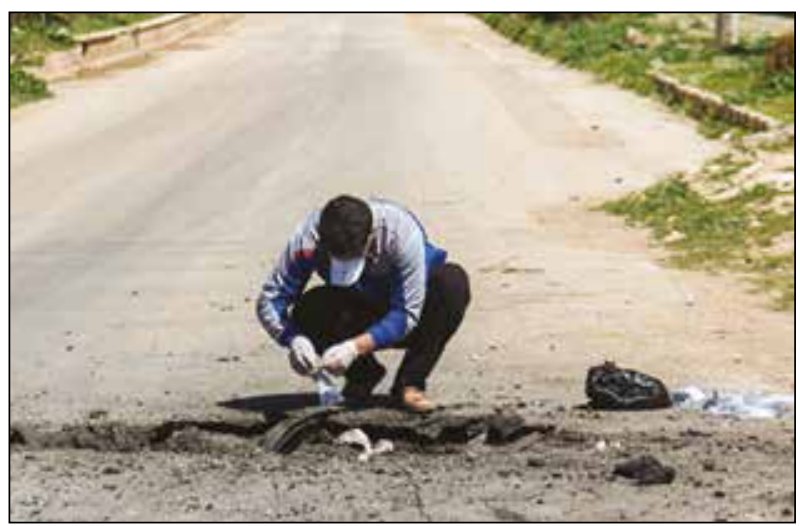

Рисунок 15 - Сбор образцов на месте «падения бомбы с зарином» в г. Хан-Шейхун 5 апреля 2017 г. .

Это повтор старого сюжета на тему «газ прошел». Фальсификаторы исходят из того, что зарин мгновенно улетучивается. Но зарин совсем не летучий и при взрыве авиабомбы не менее трети его количества, находившегося в бомбе, должно было быть «вбито» в почву, где находится этот «сбориик образцов». То есть «сборщик» стоит на пропитанной зарином почве в шлепанцах и в плотном облаке пара зарина, почти в 5 раз более тяжелого, чем воздух. На нем висящая на носу хирургическая маска. Руками в перчатках для сбора строительного мусора он копается в якобы воронке от химической авиабомбы. На кого это рассчитано? После опубликования такого «доказательства» дальше уже не о чем разговаривать

1 Химический фейк в Идлибе. URL: https:// colonelcassad.livejournal.com/3356267.html (дата обращения: 17.07.2018 г.).

ственности». После чего последовали осуждающие так называемую «сирийскую химатаку» заявления МИД Турции, Германии, Канады, США, Франции, Великобритании, генсека НАТО;

16.30 - ливанское новостное агентство «АльМасдар Ньюс» подвергло сомнению факт отравления жителей зарином. В пользу своих сомнений агентство привело пример того, что на видео- и фотоматериалах, посвященных инциденту в ХанШейхуне, помощь пострадавшим оказывают представители «Белых касок», не имеющие надежных средств защиты. При этом высказывается подозрение в слишком спокойном поведении представителей данной организации в условиях чрезвычайной ситуации, что создает впечатление о постановочном характере представленного материала.

7 апреля:

С 3.42 до 3.56 - из акватории Средиземного моря в районе острова Крит с двух эсминцев воен-

Примерно за месяц до провокации Хан-Шейхуне представитель сирийского Министерства обороны выступил с заявлением о ее подготовке боевиками в этом районе и возможном применении химического оружия. URL: https://theins.ru/news/115179 (дата обращения: 17.07.2018 г.).

293 апреля никаких ударов сирийская авиация по объектам террористов в населенном пункте Хан-Шейхун не наносила. 


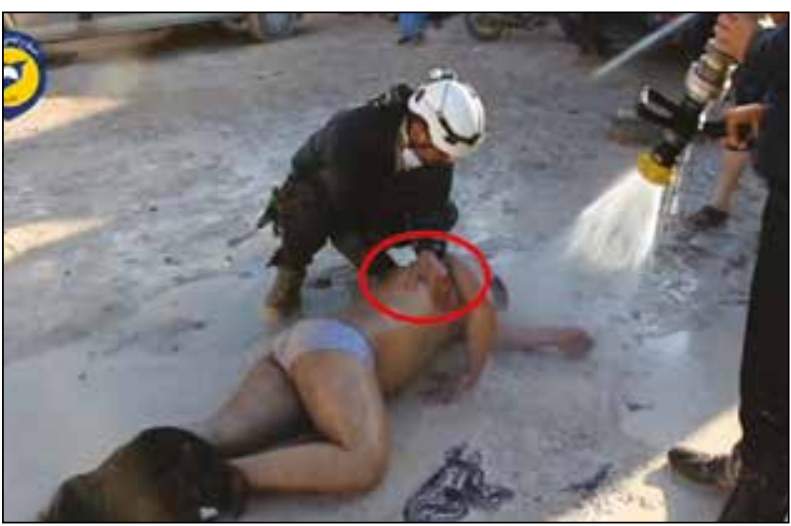

Рисунок 16- «Дегазация жертв применения зарина режимом Асада» в г. Хан-Шейхун'.

Снова сюжет на тему «газ прошел». На территории, где якобы применялся зарин, «спасатели» проводят дегазацию водой и без средств индивидуальной защиты. Фальсификаторы не имеют представленийо физико-химических и токсических свойствах зарина. Зарин хорошо растворяется в воде без утраты токсических свойств. Для реальной дегазации этой территории требуется специальная техникаи десятки тонн щелочных дегазирующих растворов. Люди, проводящие дегазацию, должны быть одеты в костюмы типа российского Л-1 и в общевойсковые противогазы, предварительно тщательно подогнанные и проверенные

\begin{abstract}
${ }^{1}$ Химический фейк в Идлибе. URL: https:// colonelcassad.livejournal.com/3356267.html (дата обращения: 15.07.2018 г.).
\end{abstract}

но-морских сил США («Росс» и «Портер») был нанесен массированный удар 59 крылатыми ракетами «Томагавк» по сирийской авиабазе аш-Шайрат в провинции Хомс.

В информационном плане подход к фабрикации «доказательств» применения «химического оружия» в г. Хан-Шейхун 4 апреля 2017 г. полностью скопирован с «химической атаки» 21 августа 2013 г. в пригороде Дамаска Восточная Гута. Рассмотрим фотографии, сделанные в Хан-Шейхуне, выдаваемые за свидетельство применения зарина "режимом Асада» (рисунки 15,16 ).

В повторяемости плагиата химических нападений, приводящего к безнаказанным убийствам людей, нет ничего удивительного. Провокация в
Восточной Гуте 2013 г. отпора на информационном поле не получила, по политическим причинам не стали выяснять, как и кто в действительности убил этих детей - значит, такие провокации можно повторять столько, сколько потребуется. Сыграла свою роль и самоуспокоенность «экспертного сообщества», воспринявшего запрет химического оружия буквально, что привело к постепенной утрате знаний не только о его поражающем действии, но и о средствах защиты от химических нападений. Уже много лет усиленно навязываемая система образования, когда события подаются фрагментарно, вне диалектической связи друг с другом, сформировала мышление, не способное связывать друг с другом даже близкие по времени события, например, «химические атаки» в Восточной Гуте 2013 г. и в г. Хан-Шейхун в 2017 г. А это означает, что можно формировать «общественное мнение» любыми картинками, лишь бы пострашнее они выглядели.

Фото- и видеоподлоги с убийством «борцами с режимом» десятков детей не вызвал никакого осуждения на Западе ни в 2013 г., ни позже. Складывается впечатление, что практика убийства детей для создания «картинки» стала стандартным информационным приемом воздействия на население западных стран ${ }^{30}$. На основе таких изображений осуществлен ракетный удар по Сирии с эсминцев США, а 7 апреля проведен брифинг, на котором президент США без всякой тени смущения заявил: «Он (Асад) нарушил конвенцию ООН по химическому оружию» (рисунок 17).

Основываясь на докладе О3ХО S/1510/2017 от 29 июня 2017 г. $^{31}$, рассмотрим, какой доказательной базой ретроспективно обосновывалось нападение на суверенную страну, члена $\mathrm{OOH}^{32}$.

В докладе представлены материалы, собранные Совместным механизмом Организации по запрещению химического оружия - Организации Объединенных Наций по расследованию случаев применения химического оружия в Сирии (далее СМР), включающие данные, предоставленные МУФ, а также информацию, полученную СМР при опросах свидетелей, выводы из экспертных заключений, подготовленных неназванными, в том числе криминалистическими организациями и отдельными экспертами. Разумеется, свою роль сыграли результаты хими-

\footnotetext{
3030 августа 2018 г. министр иностранных дел Сирии Валид Муаллем заявил, что члены организации «Белые каски» похитили 44 ребенка для того, чтобы использовать их при инсценировке химической атаки в Идлибе // Газета.ru. 2018. 30 августа. URL: https://www.gazeta.ru/army/news/2018/08/30/11970967.shtml (дата обращения: 31.08.2018 г.).

31 Report of the OPCW Fact Finding mission in Syria regarding an alleged incident in Khan Shaykhun, Syrian Arab Republic, April 2017. S/1510/2017 от 29 июня 2017 г.

32 Нападение США произошло через трое суток после того, как в социальных сетях и электронных СМИ появились ужасающие сцены массовой гибели детей в Хан-Шейхуне. Доклад S/1510/2017 опубликован только 29 июня 2017 г., т.е. речь идет именно о ретроспективной доказательной базе. На момент нападения НАТО на Сирию доказательной базы не требовалось, хватило постановочных картинок.
} 
Сирийская «химическая война»
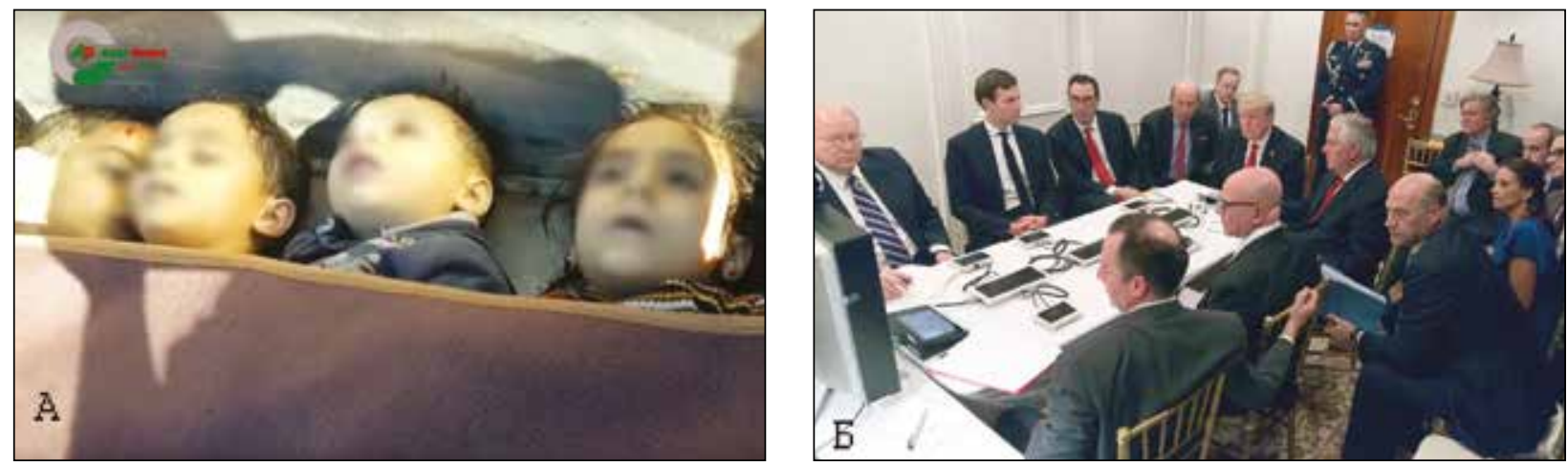

Рисунок 17 - Информационный прием обоснования нанесения ракетного удара по объектам в Сирии - убийство детей. А. Дети, похищенные и убитые террористами для показа «жертв применения зарина режимом

Асада» в г. Хан-Шейхун'. Сравните срисунком 10-тот же возраст, тоже расположение трупов. Никаких признаков дегазации тел и одежды. Б. Реакция на это убийство- брифинг 7 апреля 2017 г. президента США Дональда Трампа и руководства администрации США по поводу только что нанесенного ракетного удара по объектам в Сирии 2 . Запомним их. На фотографии за столом (слеванаправо по кругу вокруг стола):Джо Хагин - заместитель начальника Штаба по операчиям; Джаред Кушнер - зять Трампа; Стивен Мнучин - министр финансов США; Уилбур Росс - министр торговли США; Шон Спайсер - пресс-секретарь Белого дома (он и опубликовал это фото). Сидят в углу:Дональд Трамп - президент США; Рекс Тиллерсон - госсекретарь США; Герберт Макмастер - советник президента США по национальной безопасности, генерал; Райнс Прибус - глава аппарата Белого дома. Справа от стола: Стивен Бэннон - старший советник Трампа по политическим и стратегическим вопросам; Стивен Миллер-старший советник Трампа по политическим вопросам; Майкл Антон советник Трампа по национальной безопасности; Дина Пауэлл - заместитель советника Трампа по вопросам национальной безопасности; Гэри Кон - старший помощник по экономической политике. В брифинге -удаленно, по телесвязи - приняли участие виче-президент СШАМайк Пенс, Джеймс Мэттис-министр обороны США и Джозеф Данфорд-председатель объединенного комитета начальников итабов

\footnotetext{
Рачева Е. Химическая атака в городе Хан-Шейхун сирийской провинции Идлиб произошла 4 апреля. Погибло не менее 89 человек, пострадали больше 557 // Политика. 2017. № 38. 12 апреля. URL: https://www. novayagazeta.ru/articles/2017/04/12/72116-samolet-videli-ili-slyshali-pochti-vse (дата обращения: 20.07.2018 г.).

2 Чемереф Ф. Удар США крылатыми ракетами по авиабазе в Шайрате - что в «сухом остатке»? URL: https:// nkfedor.livejournal.com/465355.html; https://twitter.com/PressSec/status/850362060407963650 (дата обращения: 20.07.2018 г.).
}

ческих анализов, предоставленные МУФ неназванными лабораториями, привлеченными СМР. При этом конкретные данные экспертных заключений и данные химических анализов в отчете не приводятся, что делает невозможной их оценку. Не указаны также принципы, согласно которым производился отбор свидетелей, показания которых, как неоднократно отмечается в докладе, оказались весьма противоречивыми.

Ни МУФ, ни СМР не выполняли каких-либо действий по проведению расследования непосредственно на месте инцидента. Это мотивировалось соображениями безопасности, а позднее нецелесообразностью проведения этих работ по прошествии длительного времени. В отчете не содержится каких-либо сведений о попытках СМР получить гарантии безопасности путем согласования с заинтересованными сторонами. Фотои видеоматериалы, а также пробы для анализа предоставлены МУФ и СМР неправительственными организациями, негативно настроенными по отношению к САР и находившимися в полной готовности к предстоящей химатаке. Поспешная ликвидация ими последствий инцидента, в частности, бетонирование воронки (см. рисунок 14), наводит на мысль о намеренном сокрытии улик.

Практически во всех пунктах доклада указывается на вероятностный характер сделанных частных заключений. Это, однако, не помешало авторам сделать однозначный вывод о том, что «Сирийская Арабская Республика несет ответственность за применение зарина в Хан-Шейхуне 4 апреля 2017 г.» (п. 93 Приложения 2). Данный вывод вызывает серьезные сомнения в отношении его объективности, доказательности и непредвзятости.

В отчете не содержится обсуждения и анализа военной и/или политической целесообразности применения химоружия по населенным районам какой-либо из противодействующих сторон. Такого рода целесообразность в отношении САР представляется весьма сомнительной. Также не прорабатывается в качестве наиболее вероятного сценарий применения химоружия третьими сторонами с целью компрометации САР. 


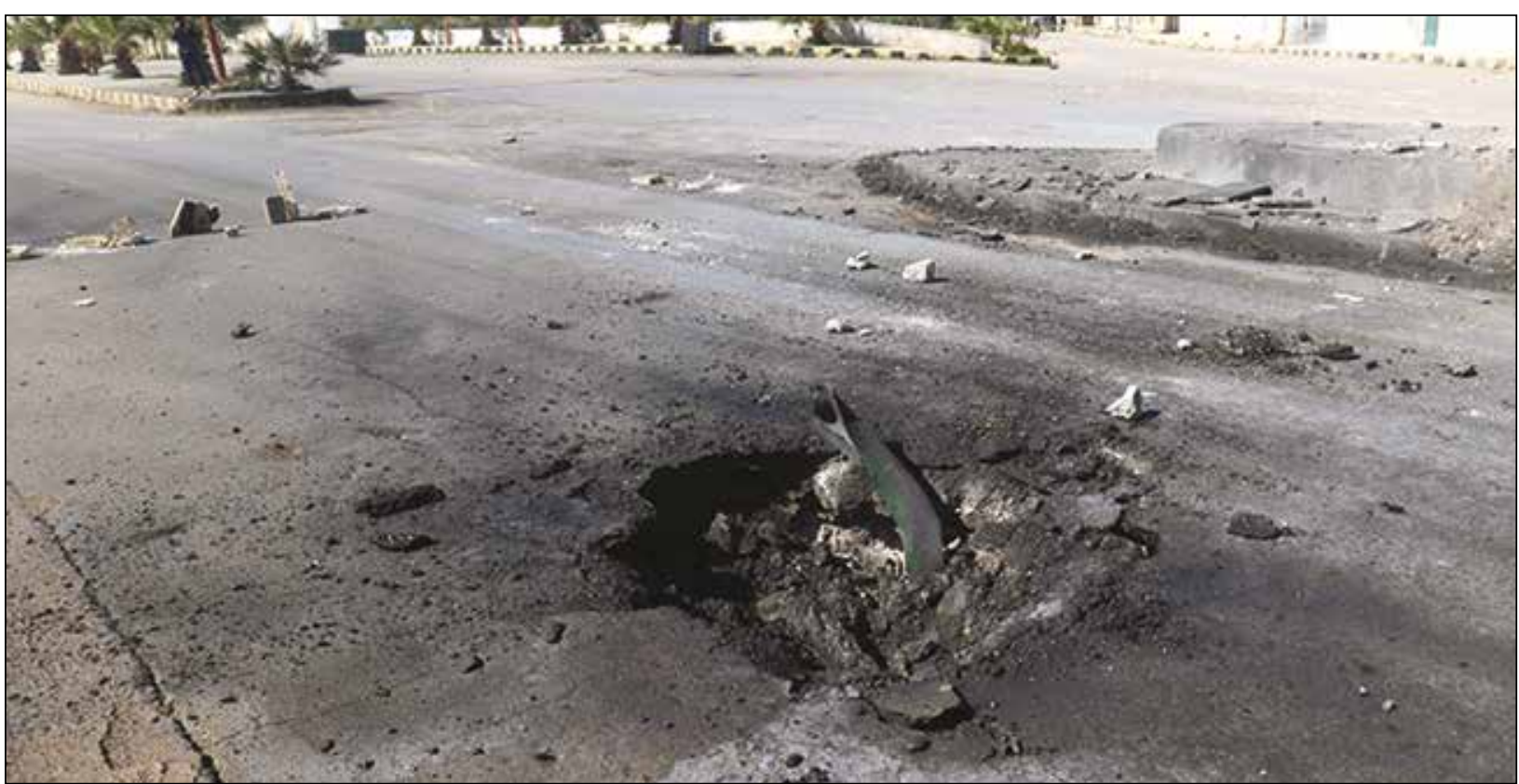

Рисунок 18 - Воронка в Хан-Шейхуне, выдаваемая за воронку от химической авиабомбы'

Огородников И. «Задача - свалить Асада»: военные эксперты о химической атаке на сирийский Хан-Шейхун. URL: https://russian.rt.com/world/article/375673-voennye-eksperty-o-himicheskoi-atake-han-sheyhun (дата обращения: 20.07.2018 г.).

Изучение представленных в отчете материалов не позволяет сделать вывод о том, что какой-либо самолет приближался на момент «химического нападения» к Хан-Шейхуну на расстояние менее 5 км.

Нигде в докладе не сообщается о находке стабилизатора авиационной бомбы, что явно бы подтвердило возникновение воронки в результате бомбометания, хотя общеизвестно, что при взрывах даже фугасных и осколочных авиабомб большей мощности стабилизатор авиабомбы всегда сохраняется и находится в районе подрыва (рисунок 18).

Характерные следы проникновения в асфальт авиабомбы отсутствуют: края воронки не вывернуты наружу, отсутствуют следы выброса грунта, форма воронки имеет почти прямоугольную форму, на поверхности асфальта нагар. Следовательно, боеприпас в момент взрыва находился на поверхности асфальта и был правильной прямоугольной формы, масса BВ в тротиловом эквиваленте оценивается в 10-12 кг. В этой связи вывод СМР по данному вопросу является не состоятельным.

В своем докладе СМР оперирует результатами химического анализа, проводившегося неназванными лабораториями, имеющими аккредитацию ОЗХО. При этом конкретные данные экспертных заключений и данные химических анализов не приводятся. И если сам факт наличия зарина или его прекурсоров в пробах, представленных «Белыми касками» как отобранные в Хан-Шейхуне, вопросов не вызывает (мы и не сомневались, что он там появится), то ряд других обстоятельств, касающихся данного факта, являются странными.

СМР утверждает, что, по данным анализов, зарин, выявленный во взятых якобы в Хан-Шейхуне пробах, наиболее вероятно был произведен с использованием прекурсора дифторангидрида метилфосфоновой кислоты (DF) из первоначального хранилища САР (п. 93, h).

Однако нельзя исключать возможность попадания сирийского DF в руки боевиков вследствие захвата мест его производства и хранения, а также использования его для последующего синтеза зарина (технология получения широко известна) с целью компрометирования властей САР. В п. 84 доклада приведено утверждение о том, что «результаты анализа экологических проб из Хан-Шейхуна подтверждают производство зарина бинарным способом» со ссылкой на материалы МУФ. Но в указанных материалах эта информация не приводилась.

С учетом изложенного, вывод СМР о причастности сирийских властей к производству и применению зарина в Хан-Шейхуне является бездоказательным.

Химический инцидент 4 февраля 2018 г., пригород г. Саракиб (провинция Идлиб) и химический инцидент в г. Дума (Восточная Гута) 7 апреля 2018 г. Оба нападения выглядят как карикатуры на применение химического 
оружия, фантазия провокаторов окончательно иссякла, и это было бы смешно, если бы на основе таких бесхитростных подлогов не убивали людей.

Пригород г. Саракиб. Доклад S/1626/2018 Миссии ОЗХО по установлению фактов применения химического оружия в Сирии, который посвящен инциденту, произошедшему 4 февраля 2018 г. в г. Саракиб САР ${ }^{33}$, вышел 15 мая 2018 г. В данном докладе МУФ ОЗХО пришла к выводу, что «4 февраля 2018 г. в ат-Талиле пригороде г. Саракиб, был, вероятно, использован в качестве химического оружия хлор, выпущенный из баллонов путем механического воздействия».

МУФ, ссылаясь на ограничения, связанные с безопасностью, отказалась посетить место инцидента и по установившейся уже порочной практике провела расследование дистанционно, нарушив базовый принцип «Chain of custody», предполагающий, что представители этой организации должны самостоятельно отобрать пробы и проследить за их сохранностью на всем пути до сертифицированной химической лаборатории, где должен осуществиться анализ.

В действительности же при расследовании инцидента в г. Саракиб, в соответствии с п.п. 4.9, 4.10 доклада, вещественные доказательства собирались и направлялись экспертам МУФ представителями не раз уличенной в создании фейковых новостей организации «Белые каски» ${ }^{34}$. Имеются факты, свидетельствующие, что спасатели из этой якобы гуманитарной организации на самом деле тесно связаны с террористической группировкой «Джебхат ан-Нусра» ${ }^{35}$. Таким образом, говорить о том, что вещественные доказательства, использованные МУФ, имеют несфабрикованный характер, не представляется возможным.

Химическая часть доклада МУФ является наиболее противоречивой и неоднозначной, содержит целый ряд нестыковок, что ставит под сомнение корректность выводов, сделанных на основе содержащихся в нем фактических данных и результатов анализов.

Данные, представленные в таблице 4 доклада по результатам химического анализа аутентичных проб двумя назначенными лабораториями ОЗХО, противоречат друг другу.

Так, наличие органических соединений хлора назначенной лабораторией 2 было обнаружено в 14 пробах, а назначенная лаборатория 3 ни в одной из проб их не обнаружила. Обращает на себя внимание и то, что в ряде проб присутствуют следы взрывчатого вещества (тринитротолуола), хотя, как указывается свидетелями инцидента (п.п. 5.9, 5.13, 5.51 доклада), взрыва баллонов с хлором не наблюдалось.

При этом необходимо отметить, что, как следует из таблицы 4 доклада, лабораторией 2 - в 8 пробах из 14, а лабораторией 3 - в 13 пробах из 14 идентифицированы списочные химикаты Списка 2 Конвенции (диизопропил метилфосфонат, изопропилметилфосфонат, метилфосфоновая кислота), которые к применению хлора не имеют никакого отношения. По нашему мнению, лица, добавившие в пробы этот набор «доказательств» применения зарина, были плохо проинструктированы ${ }^{36}$, однако МУФ данный факт в докладе по какой-то причине игнорирует, отмечая в п.П. 1.5 и 7.5 доклада только то, что в пробах присутствуют химикаты, которые не могут быть объяснены ни как естественно встречающиеся в окружающей среде, ни как имеющие отношение к хлору.

По-видимому, МУФ просто не хватило смелости признать, что единственным объяснением присутствия данных веществ в пробах может быть лишь то, что они были туда намерено внесены (нанесены) «Белыми касками». При этом МУФ игнорирует многочисленные факты, подтверждающие то, что «Белые каски», сотрудничающие с террористической группировкой «Джебхат ан-Нусра», обладают химикатами Списка 2 Конвенции, а также владеют технологиями производства данных веществ.

Результаты анализа проб на содержание анионов и катионов (таблица 5 доклада), а также результаты анализа проб растительности (таблица 6 доклада), полученные назначенными лабораториями, не могут в полной мере подтверждать выводы, сделанные МУФ в п.п. 5.60 и 7.4(c) доклада о «необычном присутствии хлора в местной окружающей среде» по следующим обстоятельствам:

\footnotetext{
${ }^{33}$ Report of the OPCW Fact Finding mission in Syria regarding an alleged incident in Saraqib, Syrian Arab Republic on 4 February 2018. S/1626/2018, 15 мая 2018 г. URL: https://www.opcw.org/fileadmin/OPCW/S_series/2018/en/s1626-2018_e_.pdf (дата обращения: 20.07.2018 г.)

${ }^{34}$ Политолог назвал «Белые каски» проектом британских спецслужб. URL: https://ria.ru/ syria/20180420/1519065937.html (дата обращения: 10.05.2018 г.).

35 Убирают свидетельства постановочности действий: почему в США заговорили об эвакуации «Белых касок» из Сирии. URL: https://pravdoryb.info/ubirayut-svidetelstva-postanovochnosti-deystviy-pochemu-v-sshazagovorili-ob-evakuatsii-belykh-kasok-iz-sirii-146112.html (дата обращения: 17.07.2018 г.).

36 Первоначальный замысел провокации состоял в имитации нападения с зарином, а потом кураторы зарин поменяли на хлор, но тех, кто должен был сфальсифицировать пробы, не предупредили о смене сценария.
} 
В.А. Ковтун, Д.П. Колесников, М.В. Супотницкий, Н.И. Шило
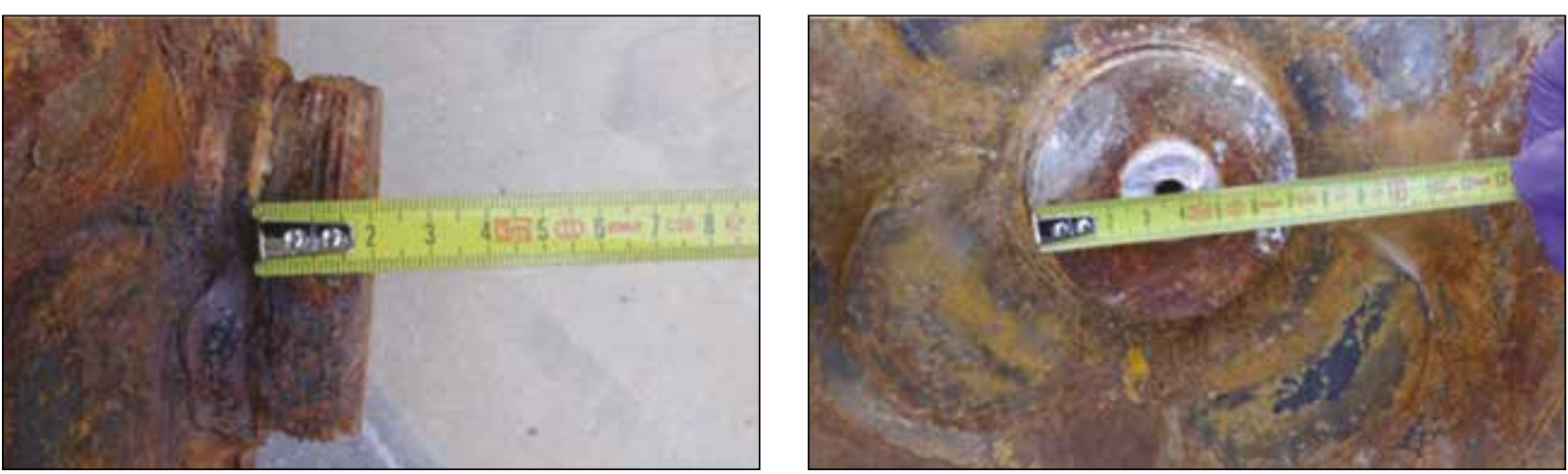

Рисунок 19 - Ржавый баллон (рисунок 12 доклада).

Ржавчина на баллоне значительно старше, чем две недели, прошедшие смомента якобы использования баллонов для доставки и высвобожденияхлора

в таблицах 5 и 6 представлены результаты анализов, полученные только в одной лаборатории, хотя, по заявлению МУФ, анализы проводили две назначенные лаборатории;

лабораториями при анализах не использовались бланковые (фоновые) пробы из района, в котором произошел инцидент. Следовательно, фактически нельзя утверждать, что «концентрация хлоридов в пробах из объектов окружающей среды - выше той, которая может встречаться естественно» (п. 5.60 доклада);

превышение в окружающей среде ионов хлора можно объяснить точно так же, как и превышение содержания ионов калия и аммония, сделанное МУФ в п. 5.56 доклада, а именно засолением почвы в результате применения минеральных удобрений.

Возникают вопросы и к показаниям свидетелей инцидента, которых дистанционно опрашивала МУФ: никаких подтверждений того, что эти лица действительно находились в г. Саракиб, нет. При этом из семи пострадавших, присутствовавших на месте происшествия во время предполагаемого инцидента и опрошенных МУФ, три человека - это так называемые спасатели организации «Белые каски», т.е. люди Ми-6. Соответственно, опираться на их «показания» нельзя.

Недостоверность результатов опроса подтверждается и теми противоречивыми показаниями свидетелей, которые представлены в докладе. Так, например, ими было сообщено, что несколько человек подверглись воздействию хлора и потеряли сознание (п.п. 5.13, 5.15 и 5.18 доклада). При этом по прибытии в медицинское учреждение симптомов тяжелого состояния не наблюдалось (п. 5.29 доклада) и всех пострадавших выписали в течение двух часов после поступления в данное учреждение (п. 5.35 доклада).

Известно, что при отравлении хлором потеря сознания наблюдается лишь при тяжелой степени поражения высокими концентра- циями, при этом лицо синеет, пострадавший задыхается, делает попытку бежать, падает, теряет сознание, после чего происходит остановка сердца и дыхания, т.е. смерть от химического отека легких. При средних и низких концентрациях - резкие загрудинные боли, жжение и резь в глазах, слезотечение, мучительный сухой кашель, часто с приступами. Часто отравленный возбужден, однако все это время он находится в сознании. В данном случае, как указано в докладе, большинство пострадавших теряло сознание, однако посинения кожных покровов и летальных исходов зафиксировано не было, не зафиксированы и отдаленные последствия отравления хлором [30, 31].

Обращает на себя внимание и «профессионализм» действий так называемых спасателей, которые, с их слов, зная о возможном применении токсичных химикатов (п. 5.16 доклада), использовали такое «эффективное» средство защиты, как марлевая маска, а по прибытии на место инцидента, не соблюдая элементарных мер безопасности, немедленно получили поражения, при этом один из «спасателей» потерял сознание. Таким образом в заранее срежиссированном спектакле, который был разыгран «Белыми касками», появляются удобные свидетели и пострадавшие, дающие нужные показания.

Одним из обозначенных в докладе способов верификации данных является «анализ открытых источников». В частности, приводятся ссылки из блогов, «твиттера», «фейсбука», Youtube, новостных лент BBC, CNN, «Washington Times» и даже пресс-релиза Госдепартамента США. Приложение с данными ссылками озаглавлено как «Список открытых интернет-источников, относящихся к инциденту в аль-Латамне» (а не в Саракибе), что свидетельствует о том, что документ подготовлен наспех, составлен по устоявшемуся шаблону предыдущих докладов МУФ, в частности, по инциденту в аль-Латамне в марте 2017 г. Напрашивается вопрос, почему МУФ в таком случае 
Сирийская «химическая война»

не использует материалы с сайта МИД России? Или игнорирует свидетельства сирийской стороны об обнаруженных подпольных лабораториях боевиков по производству отравляющих веществ вкупе с неоднократными сообщениями сирийцев о готовящихся радикалами химических провокациях?

Как следствие - собранная так называемая доказательная база оказалась крайне неубедительной. Не случайно, что в докладе и выводах, сделанных в нем, в очередной раз присутствуют такие слова, как «возможно», «вероятно», «можно предположить» и т.д. В докладе указывается, что два разбитых и искореженных баллона из-под хлора, предположительно использовавшиеся во время инцидента для доставки и диспергирования химикатов, были получены МУФ 19 февраля 2018 г. вместе с образцами почвы и растительности, взятыми, как были проинформированы члены миссии, «Белыми касками» 5 февраля 2018 г. МУФ обследовала эти два баллона и отобрала с них собственные пробы 19 февраля 2018 г. Другими словами, МУФ получила обломки баллонов через 2 недели после инцидента.

МУФ отмечается, что на баллонах виднелась ржавчина, причем больше всего - на верхней, а также на внутренних поверхностях. Из анализа фотографий (рисунки 12-14 доклада) видно, что малоразрушенные верхние части баллонов (в том числе на одном из них цилиндр с левой резьбой, на которую навертывается предохранительная цилиндрическая крышка баллона) покрыты сильной ржавчиной, которая значительно старше, чем две недели, прошедшие с момента якобы использования баллонов для доставки и высвобождения хлора (рисунок 19).

На рисунке 20 (рисунок 14 доклада) просматривается достаточно чистое от ржавчины отверстие для ввинчивания основания вентиля. Если в первом случае (рисунок 19) можно предположить, что вентиль баллона сломался от удара, то во втором случае (рисунок 20) возникает вопрос, куда и как исчез вентиль? Либо он был вывернут после обнаружения баллона (тем более, что, как следует из доклада (п. 5.41), баллоны, или хотя бы один из них, перемещались), либо его не было вообе. Тогда надо ответить на вопрос, использовался ли этот баллон для доставки хлора к месту применения, или это просто некий баллон, который был принесен на место инцидента «борцами с режимом»?

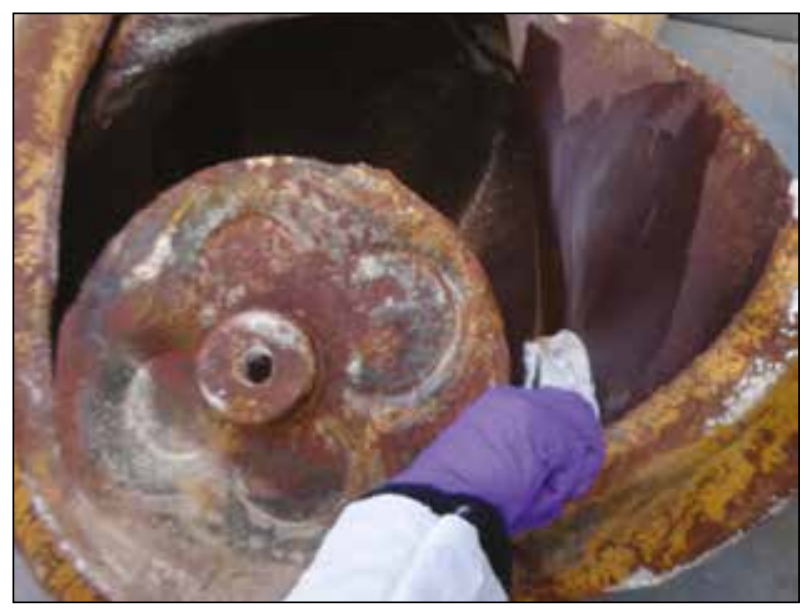

Рисунок 20 - Чистое от ржавчины отверстие для ввинчивания вентиля, свидетельствующее, что этот баллон не использовался для доставки хлора

Таким образом, представленные в докладе МУФ «доказательства и аргументы» таковыми не являются, а представляют собой набор не связанных между собой фактов, т.е. примитивно выполненный подлог. Можно с большой уверенностью полагать, что в пригороде города Саракиб 4 февраля 2018 г. имело место очередное театральное представление «Белых касок», имевшее целью усилить международное давление на Дамаск.

“Химический иниидент»в г. Дума. О театральном представлении 7 апреля 2018 г. в г. Дума было известно за несколько дней до того, как актеры появились на сцене. Начальник российского центра по примирению враждующих сторон в Сирии генерал-майор Ю.Г. Евтушенко за двое суток до постановки публично предупредил о возможных провокациях «Джебхат ан-Нусры» и «Сирийской свободной армии» с использованием кустарно изготовленных боеприпасов с хлором в подконтрольных районах, включая населенные пункты на юге Сирии. Еще раньше на совместной пресс-конференции с президентом Турции Реджепом Эрдоганом по итогам российско-турецких переговоров аналогичное заявление сделал президент России В.В. Путин ${ }^{37}$. Один такой «авиационный боеприпас» с жестяным стабилизатором, следами мучительного волочения по лестнице и приоткрытым вентилем «для запаха» нашли в постели местного жителя (рисунок 21) ${ }^{38}$.

При осмотре остатков пробитой крыши специалисты войск РХБ защиты обнаружили

\footnotetext{
37 Псевдохимическая атака в Восточной Гуте чревата военным столкновением России и CШA. URL: http:// www.4pera.ru/news/picture_of_the_day/psevdokhimicheskaya_ataka_v_vostochnoy_gute_chrevata_voennym_ stolknoveniem_rossii_i_ssha/ (дата обращения: 20.06.2018 г.). Something is very wrong and not adding up with the chemical attack site in Syria's Duma. URL: http://www.fort-russ.com/2018/04/something-is-very-wrong-and-notadding-up-with-the-chemical-attack-site-in-syrias-duma/ (дата обращения: 20.06.2018 г.).

${ }^{38}$ Пешков А. В постели с хлором. URL: https://tvzvezda.ru/news/vstrane_i_mire/content/201804261427-lic2.htm (дата обращения: 27.05.2018 г.).
} 


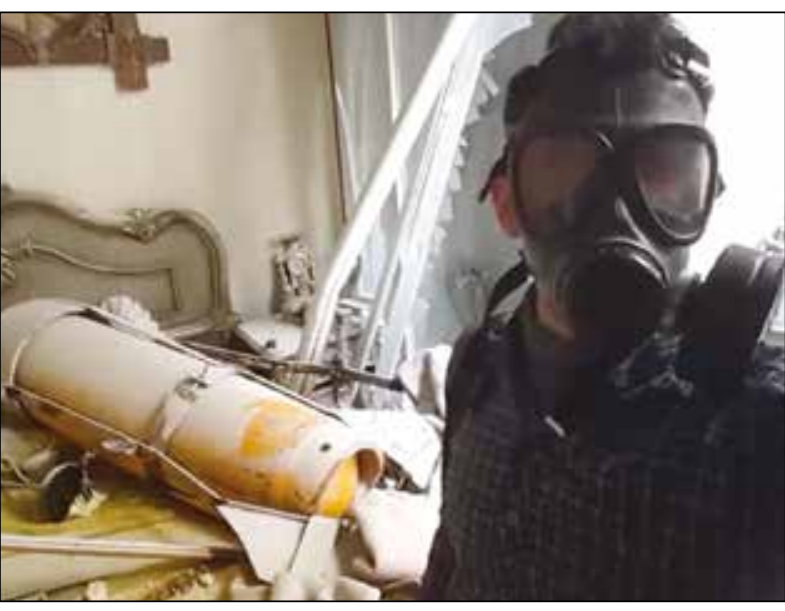

Рисунок 21 - «Авиационный химический боеприпас» 8 постелижителяг.Дума'.

Баллон схлором якобы «упал» с высоты около 2 км и пробил крышу, но ни он сам, ни его жестяные «стабилизаторы"), ни кровать не повреждены

Санаткин К. Российскими специалистами разоблачено фейковое видео «Белых касок». URL: https:// www.politforums.net/syria/1524774815.html (дата обращения: 27.05.2018 г.).

хвостовик реактивного снаряда, который, видимо, и стал причиной пролома в потолке. Кроме того, мы не исключаем того, что пролом в потолке сделан вручную, так как в подъезде был обнаружен лом. Сам баллон явно занесли с улицы, на что указывают сколы на лестнице и следы волочения по кафелю. Баллон не пострадал. Редуктор не сорван и лишь слегка приоткрыт для постоянного стравливания газа.

Бросается в глаза падение стиля и уровня типовой химической провокации, произошедшее за годы войны в Сирии. Сравните «боеприпас» на рисунке 21 с «боеприпасом», показанным на рисунке 11. Еще 4 года назад провокаторы «упаковывали» баллон в старую ржавую железную трубу, приваривали к ней хоть и ржавые, но все же стабилизаторы (а не лепили вокруг баллона какие-то обручи и хомуты), и даже имитировали подрывной заряд. Теперь, судя по фотографии на рисунке 21, они действуют по принципу «и так сойдет». Оно и сошло. Достаточным оказалось одного видеоролика пособников террористов о мас- совой гибели детей, которых они обычно сами и убивают, для того, чтобы в ночь с 13 на 14 апреля США, Франция и Великобритания нанесли ракетные удары по Сирии.

Приведенные данные показывают абсолютную лживость обвинений в адрес сирийского руководства в применении химического оружия в Сирии. За годы войны в Сирии стали очевидными непригодность для установления истины тех механизмов, которые использует ОЗХО; и поверхностный подход к проведению расследований специалистами СМР и МУФ. Очень серьезную обеспокоенность вызывает активное развитие крайне примитивной постановочной части химических провокаций, как в сравнении с аналогичной ложью 1990-х гг. в отношении нарушения КБТО, так и КХО в начальном периоде сирийской войны. Это обстоятельство говорит о том, что после ухода с мировой арены СССР, не получая должный отпор уже более 30 лет, современные элиты Запада не воспринимают реальной опасности, исходящей от их же собственных действий. Высокомерно выдумывая предлоги для объявления «изгоем» то или иное государство, нагромождая одну ложь на другую, распространяя и информационно поддерживая глобальный терроризм (теперь уже с применением химического оружия), они утратили понимание реальной картины мира и стали заложниками своих собственных фейковых фантазий. Рассматривая примитивные химические фейки в Сирии как частный случай в контексте современной геополитики, мы предполагаем, что речь идет не только о Ближнем Востоке, но и о формировании очередного «крестового похода» на Россию и ее союзников, теперь уже с применением оружия массового поражения. Основным прикрытием такого похода, casus belli, будут фейковые новости в глобальных СМИ. Однако в этой связи не будет лишним еще раз напомнить, что Россия - суверенная страна с огромным военным и экономическим потенциалом, и стойким народом. За свою историю она уже не один раз приводила к осознанию реальной картины миры очередных «исключительных». И хорошо бы нашим оппонентам также вспомнить, чем окончились предыдущие «крестовые походы».

Информация о конфликте интересов

Авторы заявляют, что исследования проводились при отсутствии любых коммерческих или финансовых отношений, которые могли бы быть истолкованы как потенциальный конфликт интересов.

Сведения о рецензировании

Статья прошла открытое рецензирование двумя рецензентами, специалистами в данной области. Рецензии находятся в редакции журнала. 


\section{Список источников}

1. Павлович М.П. Химическая война и химическая промышленность. М., 1925.

2. Churchill W.S. The World Crisis. Part II. 1915. London, 1929.

3. Simon J., Hook R. Word war I gas warfare tactics and equipment. Oxford: Osprey Publishing, 2007.

4. Де-Лазари А.Н. Химическое оружие на фронтах Мировой войны 1914-1918 гг.: Краткий исторический очерк. Науч. ред. и коммент. М.В. Супотницкого. М., 2008.

5. Farrow E. Gas Warfare. N.Y.. 1920.

6. Ганслиан Р., Бергендорф Ф. Химическое нападение и оборона. М., 1925.

7. Майер Ю. Отравляющие вещества и их боевое применение. Часть II. М., 1928.

8. Красильников М.В. Военно-химическое дело русской армии в Первой мировой войне (образование и развитие). Часть II. Кампания 1916 г.: Дис. ... д-ра воен. наук. М., 1952.

9. Medical aspects of chemical and biological warfare / Ed. Sidell F. R., Tafuqi E.T., Franz D.R.. Washington, 1997.

10. Old Chemical Weapons: Munitions Specification Report. U.S. Army Chemical Materiel Destruction Agency, 1994.

11. Army equipment data sheets. Chemical weapons and munitions. Technical manual. TM 43-0001-26-2. Department of the Army, 1982.

12. Антонов Н.С. Химическое оружие на рубеже двух столетий. М., 1994.

13. Medical aspects of chemical warfare [Ed. Shirley D. Tuorinsky]. Washington, 2008.

14. Патент США № 6227118, 15.07.1968; опубликован 08.05.2001 г.
15. Татарченко Е. Воздушные силы в италоабиссинской войне. М., 1940.

16. US Departments of the Army, Navy and Air Force. Employment of chemical and biological agents. March, 1966 (FM 3-10; NWIP 36-2; AFM 355-4 FMFM 11-3).

17. Meyssan Th. Sous nos yeux: Du 11 Septembre à Donald Trump... (French Edition). Paris, 2017.

18. Фукуяма Ф. Конец истории и последний человек. М., 2007.

19. Энгдаль У.Ф. Священные войны Западного мира. М., 2015.

20. Engdahl W. Century of War: Anglo-American Oil Politics and the New World Order. 2008.

21. Handbook of toxicology of chemical warfare agents. Second ed. / Ed. Gupta R.C. London, 2015.

22. Каракчиев Н.И. Токсикология ОВ и защита от оружия массового поражения. Ташкент, 1973.

23. Franke S. Lehrbuch der Militärchemie. Band 1. Deutscher Militärverlang. Berlin, 1967.

24. Жигур Я.М. Химическое оружие в современной войне. М.: 1936.

25. Майер Ю. Отравляющие вещества и их боевое применение. Часть І. М., 1927.

26. Fries A.A., West C.J. Chemical warfare. N.Y., 1921.

27. Фишман Я.М. Военно-химическое дело.

Пособие для начальствующего состава. М., 1929.

28. Фишман Я.М. Военно-химическое дело в современной войне. М., 1930.

29. Широкорад А.Б. Чудо-оружие Российской империи. М., 2005.

30. France B.E.P. An atlas of gas poisoning. N.Y., 1918.

31. Sartori M. The war gases. Chemistry end analysis. N.Y.: 1939.

\section{Об авторах}

Федеральное государственное бюджетное учреждение «27 Научный центр» Министерства обороны Российской Федерации, 105005, Российская Федерация, г. Москва, Бригадирский переулок, д. 13.

Ковтун Виктор Александрович. Начальник центра, канд. хим. наук, доц.

Колесников Дмитрий Петрович. Заместитель начальника центра, канд. техн. наук, доц.

Супотницкий Михаил Васильевич. Главный специалист, канд.биол.наук, ст. науч. сотр.

Шило Наталья Игоревна. Младший научный сотрудник, научный редактор.

Контактная информация для всехавторов: 27nc_1@mil.ru Контактное лицо: Супотницкий Михаил Васильевич; 27nc_1@mil.ru 


\title{
SYRIAN «CHEMICAL WAR»
}

\author{
V.A. Kovtun, D.P. Kolesnikov, M.V. Supotnitskiy, N.I. Shilo \\ Federal State Budgetary Establishment «27 Scientific Centre» of the Ministry of Defence \\ of the Russian Federation, Brigadirskii Lane 13, Moscow 105005, Russian Federation
}

\begin{abstract}
This article shows that the Syrian Arab Republic (SAR) was doomed for destruction by the «collective West» at least since 2002 within the framework of the process of fragmentation of the states of the Greater Middle East and bringing the Muslim Brotherhood to power in these countries. Later this process was called the Arab Spring. The analysis of the alleged «facts» of the use of chemical weapons by the Syrian Armed Forces made it possible to establish that they were nothing more than primitive artificial performances. No «chemical attack» in Syria, attributed to the Syrian army, pursued military objectives. The basic principles of the use of chemical weapons in combat were ignored. Not a single case of the use of factory-loaded chemical munitions has been recorded. Information attacks of the Western media and non-governmental organizations, as well as their claims about the «Asad's regime»'s «chemical war against its own people» were carried out to support the Syrian anti-governmental forces at the time of their offensive on the government-controlled territory, or when they were defeated by the Syrian army. Since 2013 the opposition has been practicing mass abductions and murders of children in order to obtain more convincing «pictures». But these crimes did not attract any attention of the Western governments or human rights organizations. The article also presents the evidence of systemic failures and shortcomings in the work of the OPCW - UN Joint Investigative Mechanism (JIM) and the OPCW Fact Finding Mission (FFM), formed to establish the facts surrounding allegations of the use of toxic chemicals for hostile purposes in Syria. Considering staged fake chemical attack in Syria within the context of modern geopolitics, we can assume that it is possible to talk about the new "crusade» on Russia and its allies, but with the use of weapons of mass destruction. After the retrospective analysis of the mechanisms of information warfare, we may also note the deep intellectual degradation of its organizers in comparison with the similar information operations of the 1990s. This circumstance poses a serious threat not only to Syria and Russia, but to other countries as well, because the organizers of these operations are unable to assess even the immediate impacts of their actions.
\end{abstract}

Keywords: aircraft-delivered chemical munition; White Helmets; Muslim Brotherhood; binary chemical munition; decontamination; sarin; OPCW; toxic agent; Syrian Arab Republic; toxic chemical; chemical war; chlorine.

For citation: Kovtun V.A., Kolesnikov D.P., Supotnitskiy M.V., Shilo N.I. Syrian "Chemical War» // Journal of NBC Protection Corps. 2018. V. 2. № 3. P. 7-39.

\section{Conflict of interest statement}

The authors declare that the research was conducted in the absence of any commercial or financial relationship that could be construed as a potential conflict of interest.

Peer review information

The article has been peer reviewed by two experts in the respective field. Peer reviews are available from the Editorial Board. 


\section{References}

1. Pavlovich M.P. Chemical war and chemical industry M.: 1925 (in Russian).

2. Churchill W.S. The World Crisis. Part II 1915. London, 1929.

3. Simon J., Hook R. Word war I gas warfare tactics and equipment. Oxford: Osprey Publishing, 2007.

4. De-Lazari A.N. Chemical weapons on the fronts of the World War 1914-1918: A brief historical essay / Sci. Ed Supotnitskiy M.V. Moscow, 2008 (in Russian).

5. Farrow E. Gas Warfare. N.Y.. 1920.

6. Ganslian R., Bergendorf F. Gas attack and defense. Moscow, 1925 (in Russian).

7. Mayer Yu. Chemical agents and their combat use. Part II. Moscow, 1928 (in Russian).

8. Krasilnikov M.V. Military chemical affair of the Russian army in the First World War (education and development). Part II. Campaign of 1916: Dissertation of the doctor of military sciences. Moscow, 1952 (in Russian)

9. Medical aspects of chemical and biological warfare [Ed. F. R. Sidell, E. T. Tafuqi, D. R. Franz]. Washington, 1997.

10. Old Chemical Weapons: Munitions Specification Report. U.S. Army Chemical Materiel Destruction Agency, 1994.

11. Army equipment data sheets. Chemical weapons and munitions. Technical manual. TM 43-0001-26-2. Department of the Army, 1982.

12. Antonov N.S. Chemical weapons at the turn of two centuries. Moscow, 1994 (in Russian).

13. Medical aspects of chemical warfare [Ed. Shirley

D. Tuorinsky]. Washington, 2008.

14. Patent US № 6227118 (2001).

15. Tatarchenko E. Air Force in the Italo-Abyssinian War. M.: 1940 (in Russian).
16. US Departments of the Army, Navy and Air Force. Employment of chemical and biological agents. March, 1966 (FM 3-10; NWIP 36-2; AFM 355-4 FMFM 11-3).

17. Meyssan Th. Sous nos yeux: Du 11 Septembre à Donald Trump... (French Edition). Paris, 2017.

18. Francis Fukuyama. The End of History and the Last Man. M.: 2007 (in Russian).

19. Engdahl W. Holy Wars of the West World. M.: 2015 (in Russian).

20. Engdahl W. Century of War: Anglo-American Oil Politics and the New World Order. 2008.

21. Handbook of toxicology of chemical warfare agents. Second edition [Ed. Ramesh C. Gupta]. London, 2015.

22. Karakchiev N.I. Toxicology and WMD protection. Tashkent, 1973 (in Russian.

23. Franke S. Lehrbuch der Militärchemie. Band 1. Deutscher Militärverlang. Berlin, 1967.

24. Zhigur Ya.M. Chemical weapons in modern warfare. Moscow, 1936 (in Russian).

25. Mayer Yu. Chemical agents and their combat use. Part I. Moscow, 1927 (in Russian).

26. Fries A.A., West C.J. Chemical warfare. N.Y.: 1921.

27. Fishman Ya.M. Military chemical arts. A manual for the commanding staff. Moscow, 1929 (in Russian).

28. Fishman Ya.M. Military chemical arts in modern warfare. M.: 1930 (in Russian).

29. Shirokorad A.B. Wonder weapons of the Russian empire M.: 2005 (in Russian).

30. France B.E.P. An atlas of gas poisoning. N.Y.: 1918.

31. Sartori M. The war gases. Chemistry end analysis. N.Y.: 1939.

Authors

Federal State Budgetary Establishment «27 Scientific Centre» of the Ministry of Defence of the Russian Federation. Brigadirskii Lane 13, Moscow 105005, Russian Federation.

Kovtun Viktor Aleksandrovich. Head of the Centre. Candidate of Chemical Sciences, Associate Professor.

Kolesnikov Dmitry Petrovich. Deputy Head of the Centre. Candidate of Technical Sciences, Associate Professor.

Supotnitskiy Mikhail Vasilyevich. Senior researcher. Chief Specialist, Candidate of Biological Sciences. Shilo Natalya Igorevna. Junior Researcher, Scientific Editor.

Contact information for all authors:27nc_1@mil.ru Contact person: Supotnitskiy Mikhail Vasilievich; 27nc_1@mil.ru 